\title{
SANDSAGE PRAIRIE: FLORISTICS, STRUCTURE, AND DYNAMICS OF A GREAT PLAINS PLANT COMMUNITY
}

\author{
James H. Locklear \\ Lauritzen Gardens \\ 100 Bancroft Street \\ Omaha, Nebraska 68108, U.S.A. \\ j.locklear@omahabotanicalgardens.org
}

\begin{abstract}
Sandsage prairie is a shrub-steppe ecological association unique to the Great Plains of North America in which sand sagebrush, Artemisia filifolia, is the dominant and diagnostic element. This paper presents the first comprehensive account of the floristics, community structure, and vegetation dynamics of sandsage prairie throughout its distribution. Sandsage prairie occurs in discontinuous tracts throughout western parts of the central and southern Great Plains in association with dune fields and other areas of sand habitat. The most conspicuous element of the vegetation is shrub-steppe dominated by Artemisia filifolia with a moderate to dense herbaceous layer dominated by perennial grasses. The relative density of Artemisia filifolia canopy cover in the landscape can range from $10 \%$ to $50 \%$ and is influenced by topographic gradient, climatic variability, fire history, grazing history, and past range management practices. Occurring in mosaic with the shrub-steppe component of sandsage prairie are intergrading but distinct assemblages of herbaceous species tied to varying degrees of disturbance and stabilization within the dune field. A total of 119 plant taxa in 33 families are characteristic of sandsage prairie in the Great Plains, with Poaceae, Asteraceae, Fabaceae, Euphorbiaceae, and Onagraceae the largest families (in descending order). There is a pronounced northsouth gradient to the associated flora, with 34 species ( $29 \%$ of the total) being restricted to or most prevalent in either northern or southern stands of sandsage prairie. Sandsage prairie occurs in highly dynamic habitat subject to a host of natural disturbance factors and as a consequence exhibits a high level of heterogeneity in community structure with frequent shifts in species composition and dominance.
\end{abstract}

\section{RESUMEN}

La pradera de artemisia es una asociación ecológica de estepa arbustiva única de las Grandes Llanuras de Norteamérica en la que Artemisia filifolia es el elemento dominante y diagnóstico. Este artículo presenta el primer informe complete de la florística, estructura de la comunidad, y dinámica de la vegetación de la pradera de artemisia en toda su distribución. La pradera de Artemisia aparece en extensiones discontinuas en la parte occidental del centro y sur de las Grandes Llanuras en asociación con campos de dunas y otras áreas de hábitat arenoso. El elemento más visible de la vegetación es el matorral dominado por Artemisia filifolia con un estrato herbáceo de moderado a denso dominado por gramíneas perennes. La densidad relativa de la cubierta de Artemisia filifolia en el paisaje varía del 10\% al $50 \%$ y está influenciado por el gradiente topográfico, variabilidad climática, fuego histórico, pastoreo anterior, y prácticas anteriores de manejo. Intercalada en el mosaico del componente de matorral de artemisia existen praderas en las que se intergradan distintos conjuntos de especies herbáceas ligadas a grados variables de perturbación y estabilización en el campo de dunas. Un total de 119 taxa vegetales de 33 familias son característicos de la pradera de artemisia en las Grandes Llanuras, con Poaceae, Asteraceae, Fabaceae, Euphorbiaceae, y Onagraceae como las mayores familias (en orden descendente). Hay un gradiente pronunciado norte-sur en la flora asociada, con 34 especies (29\% del total) restringidas a más predominantes en las posiciones norte o sur de la pradera de artemisia. Esta pradera está en un hábitat muy dinámico sujeto a tener factores de perturbación natural y como consecuencia exhibe un nivel alto de heterogeneidad en la estructura de la comunidad con cambios frecuentes en la composición de especies y dominancia.

\section{INTRODUCTION}

"At evening we encamped within a few miles of the main Republican [River], on a little creek, where the air was fragrant with the perfume of artemisia filifolia.... Bare sand hills everywhere surrounded us in the undulating ground along which we were moving; and the plants peculiar to a sand soil made their appearance in abundance."

—John C. Fremont, 21 June 1843, encountering sandsage prairie in present-day northeastern Colorado

Extensive dune fields are a significant feature of the Great Plains of North America (Muhs \& Holliday 1995). The largest of these is the Nebraska Sandhills which at 49,987 sq km (19,300 sq mi) is the largest dune field in the Western Hemisphere. These areas of sandy habitat support unique biotic assemblages which are classified by NatureServe (2019) into two main ecological systems-Western Great Plains Sand Prairie and Western

J. Bot. Res. Inst. Texas 13(1): $253-278.2019$ 
Great Plains Sandhills Steppe. The latter is distinguished by a strong shrub component and is comprised of Quercus havardii-dominated sand shinnery and Artemisia filifolia-dominated sandsage prairie.

These three associations—sand prairie, sand shinnery, and sandsage prairie-are the primary expressions of vegetation occupying sand habitat in the western Great Plains (Fig. 1). The flora and ecology of sand prairie is well-documented by a long history of studies in the Nebraska Sandhills (see Bleed \& Flowerday (1990) and Johnsgard (1995) for overviews). Likewise, a significant body of literature exists for sand shinnery (see Peterson \& Boyd (1998) and Dhillion \& Mills (1999) for overviews).

In contrast, knowledge of the biology and ecology of sandsage prairie is deficient and fragmented. While useful information can be found in state-level botanical, ecological, range management, and wildlife management literature, no comprehensive description of this unique Great Plains plant community exists. Such knowledge is critically needed given the imperiled status of sandsage prairie throughout its range (Artemisia filifolia / Andropogon hallii Shrubland is ranked G3, globally vulnerable to extinction, by NatureServe) and in most of the eight states in which it occurs. This paper presents the first account of the floristics, structure, and dynamics of sandsage prairie throughout its distribution.

\section{Historical Background}

The first recorded scientific encounters with sandsage prairie came in 1820 as botanist and physician Edwin James traveled with Major Stephen Long's Expedition westward across present-day Nebraska to the Rocky Mountains in Colorado, then south into New Mexico and back east through the Texas Panhandle and across Oklahoma (Goodman \& Lawson 1995; Evans 1997). James collected the type specimen of Artemisia filifolia Torr. somewhere along the Platte or South Platte River, the label on the holotype at NY stating "Arid plains of the Platte." Kaul et al. (2011) place the type locality along the South Platte River near present-day Roscoe in Keith County, Nebraska, which the expedition traversed between June 23 and 25. In his account of the expedition for these days, James (1823) noted "extensive districts covered entirely with loose and fine sand" and the abundance of "several types of wormwood, (Artemisia)." The expedition again encountered sandsage prairie in August as they followed the Canadian River eastward from its junction with Ute Creek in northeastern New Mexico across the Texas Panhandle (Goodman \& Lawson 1995). As described by James, "the surface of the country is mostly of a loose sand, bearing tufts of wormwood [Artemisia]."

James' encounters with sandsage prairie on the Platte River and Canadian River represent the northern and southern edges of its distribution in the Great Plains. Early reports of this plant community from the interior portions of its range include that of John C. Fremont (1845), who in 1843 traversed sandy habitat on the upper reaches of the Republican River watershed in northeastern Colorado "where the air was fragrant with the perfume of artemisia filifolia," and Friedrich Adolph Wislizenus (1848) who in 1846 encountered sandhills along the Cimarron River in southwestern Kansas where "different species of artemisia...cover the whole plain."

The earliest published accounts of the floristic composition of habitat supporting sandsage prairie came at the end of the nineteenth century. Carleton (1892) described plants characteristic of "sandy regions" of the Oklahoma Panhandle and adjacent parts of Kansas and Texas based on his travels through the region in 1891. Hitchcock (1896) enumerated plants collected by C.H. Thompson in southwestern Kansas in 1893 and listed species collected in the sandhills along the Arkansas and Cimarron rivers. Hitchcock (1898) subsequently published a paper on the "Ecological Plant Geography of Kansas" in which he described "Sand-hill Vegetation." The first recognition of a plant community in which Artemisia filifolia is the diagnostic element came in 1900 when Pound and Clements described an Artemisia filifolia Formation in Phytogeography of Nebraska.

The most detailed descriptive studies of the flora and ecology of sandsage prairie have been made in eastern Colorado. In an investigation of natural vegetation as an indicator of the capabilities of land for crop production in the Great Plains, Shantz (1911) studied sandsage prairie in the Wray Dune Field in the northeastern part of the state. Shantz's study sites were revisited in the 1980s by McGinnies et al. (1991). Weaver (1919) included an analysis of 14 sandsage prairie species in his massive publication (171 pages) on the ecological relations of roots, his findings based on field work in the Black Squirrel Dune Field in east-central Colorado. 


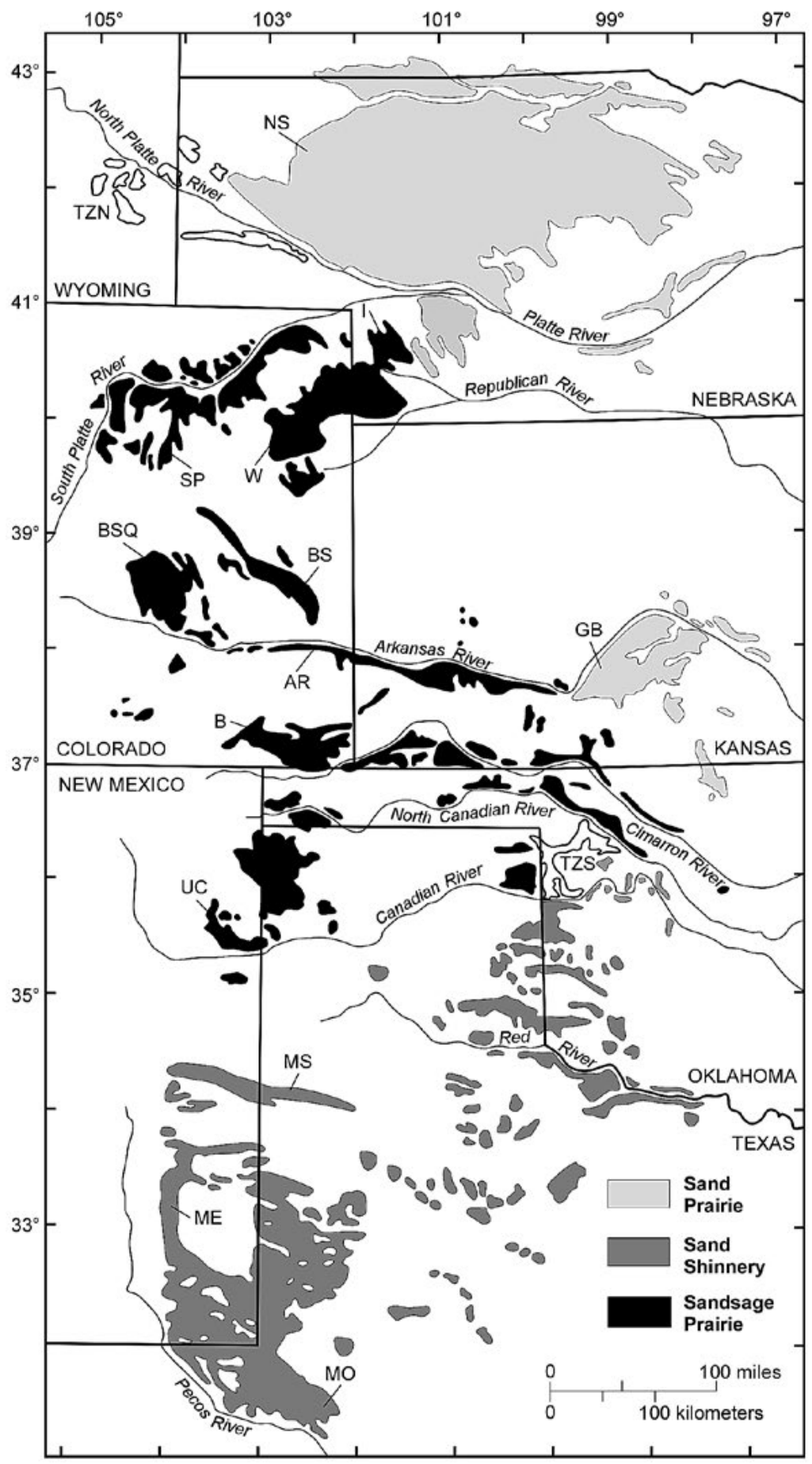

FIG. 1. Map showing the distribution of sandsage prairie in the Great Plains, USA. Dune fields: AR, Arkansas River; B, Baca; BS, Big Sandy; BSQ Black Squirrel Creek; GB, Great Bend; I, Imperial; ME, Mescalero; MO, Monahans; MS, Muleshoe; NS, Nebraska Sandhills; SP, South Platte; UC, Ute Creek; W, Wray. TZN = Transition Zone North. TZS = Transition Zone South. Dune field locations and names compiled from Muhs \& Holliday (1995, 2001) and Schmeisser et al. (2010). 
Ramaley's (1939) foundational study of sandsage prairie vegetation was based on work carried out in the South Platte Dune Field in northeastern Colorado. Daley's (1972) important master's thesis, "The Native Sand Sage Prairie of Eastern Colorado," was based on research in the South Platte, Wray, Big Sandy, and Baca dune fields. Kelso et al. (2007) studied patterns of rarity, disjunction, and succession in the dune communities in the Black Squirrel Dune Field. See Figure 1 for the locations of these dune fields.

Considerable literature exists on the impacts of grazing intensity, prescribed fire, and other rangeland management practices on sandsage prairie, with the aim of sustaining beef cattle production while maintaining or improving plant and soil resources. A number of such studies have been carried out in northwestern Oklahoma at the Hal and Fern Cooper Wildlife Management Area and the Southern Plains Range Research Station (Oklahoma State University) and in northeastern Colorado at the Eastern Colorado Research Center (Colorado State University). While focused on rangeland management, these studies yield helpful insights into the structure and dynamics of sandsage prairie. Similarly, studies aimed at understanding the ecology and conservation needs of the Lesser Prairie-Chicken (Tympanuchus pallidicinctus), an at-risk species, have contributed to better understanding of and appreciation for sandsage prairie.

To date, no comprehensive description of the floristic composition and structure of sandsage prairie throughout its range has been published, although considerable information exists in state-level botanical, ecological, range management, and wildlife management literature (Table 1).

\section{Ecological Classification and Nomenclature}

The shrub Artemisia filifolia is the dominant and diagnostic element in the flora of sandsage prairie. While sandsage prairie is an ecological association of the Great Plains, the range of Artemisia filifolia extends considerably beyond—southward into northern Mexico (Chihuahuan Desert) and westward across New Mexico into Arizona, southern Utah, and southeastern Nevada (Colorado Plateau and Great Basin). As in the Great Plains, Artemisia filifolia is often a dominant shrub of sandy habitat in these regions and is the principle indicator species of a number of plant communities, but the associated shrubs and herbaceous species in these communities have strong desert affinities (Brown 1994; MacMahon 2000) and lack the co-dominant graminoid component that characterizes sandsage prairie.

A variety of technical and nontechnical names have been used to designate Artemisia filifolia associations in the Great Plains. The fundamental issue regarding ecological classification is whether these associations should be recognized as shrubland or grassland. NatureServe (2019) treats the Artemisia filifolia / graminoid associations in the Great Plains as shrubland, as do vegetation classification systems for Colorado (CNHP 2005), Kansas (Lauver et al. 1999), Oklahoma (Hoagland 2000), and Texas (Elliott et al. 2009-2014). However, this vegetation is more accurately termed shrub-steppe, as are the various types of Artemisia-dominated associations in western North America where the herbaceous layer has a moderate to dense canopy dominated by perennial graminoids (West \& Young 2000). The technical name Artemisia filifolia steppe is here recommended.

Of the various nontechnical names used for Artemisia filifolia associations in the Great Plains (Table 2), "sandsage prairie" is used here since it is widely published in botanical, ecological, range management, and wildlife management literature and is the most often used colloquial name for this plant community.

\section{METHODS}

The study was based on direct reconnaissance of sandsage prairie occurrences by the author coupled with review of published literature. Field observations were made over several years throughout the range of sandsage prairie in the Great Plains including major dune fields and areas of sand habitat in Colorado, Kansas, Nebraska, New Mexico, Oklahoma, Texas, and Wyoming. Sandsage prairie occurrences were located with guidance from state-level vegetation maps, herbarium specimen data of diagnostic species, county soil maps, and published literature. 
TABLE 1. State-level literature providing ecological and floristic information on sandsage prairie.

Colorado: $\quad$ Shantz 1911; Weaver 1919; Ramaley 1939; Costello 1944; Rogers 1953; Daley 1972; Sims et al. 1976;

Davis \& Bonham 1979; Shaw et al. 1989; McGinnies et al. 1991; Clark 1996; Rondeau 2003; Hazlett 2004;

Kelso et al. 2007; Neid et al. 2007; Kuhn et al. 2011; Rondeau et al. 2011; Rondeau 2013; Rondeau et al. 2018

Kansas: Hitchcock 1896, 1898; Cornelius \& Atkins 1946; Simonett 1960; Richards 1968; Kuchler 1974; Rush et al. 1982; Sexson 1983; Hulett et al. 1988; Lauver et al. 1999; VanNimwegen et al. 2008; Kuhn et al. 2011

Nebraska:

New Mexico: Pound \& Clements 1900; Farrar 1993a, 1993b; Kaul \& Rolfsmeier 1993; Rolfsmeier \& Steinauer 2010; Locklear 2017b

Oklahoma: Heerwagen 1956; Dick-Peddie 1993; Griffith et al. 2006; Hazlett et al. 2009

Bruner 1931; Blair \& Hubbell 1938; Duck \& Fletcher 1944; Sherwood \& Risser 1980; Collins et al. 1987;

Sims et al. 1987; Hoagland 2000; Vermeier et al. 2001; Cordova et al. 2005; Barber 2008; Hoagland 2008;

Hazlett et al. 2009; Doxon 2011; Winter et al. 2011a, 2011b; Buthod \& Hoagland 2015

South Dakota: Von Loh et al. 1999

Texas: $\quad$ Allred 1956; Jackson 1965; Rowell 1967; Griffith et al. 2004; Nesom \& O'Kennon 2008; Hazlett et al. 2009;

Elliott et al. 2009-2014

Wyoming: $\quad$ Maxwell \& Brown 1968

TABLE 2. Colloquial names for Artemisia filifolia associations in the Great Plains.

Sand-Sage Community

Sandsage-Grassland

Sandsage-Bluestem Prairie

Sandsage Prairie

Xeric Sandhills Prairie

Sandsage Mixed-Grass Prairie

Sand Sagebrush-Mixed Prairie

Sand Sagebrush Prairie

Sand Sagebrush Shrubland

\author{
Ramaley 1939 \\ Duck \& Fletcher 1944 \\ Kuchler 1964 \\ Kuchler 1974 \\ Launchbaugh \& Owensby 1978 \\ Kaul \& Rolfsmeier 1993 \\ Berg 1994 \\ Gillen \& Sims 2006 \\ Winter et al. 2011
}

ECOLOGY

\section{Distribution}

Sandsage prairie occurs in discontinuous tracts throughout western parts of the central and southern Great Plains, the total range extending approximately $600 \mathrm{~km}$ (375 mi) from north to south (Fig. 1). Kuchler (1985) mapped major occurrences of sandsage prairie in southwestern Nebraska, eastern Colorado, southwestern Kansas, and western Oklahoma. Significant tracts also occur in northeastern New Mexico and the upper part of the Texas Panhandle. Detailed state-level mapping of sandsage prairie is available for Colorado (Rondeau et al. 2011), Kansas (Kuchler 1974), Nebraska (Kaul \& Rolfsmeier 1993), Oklahoma (Hoagland 2008), and Texas (Elliott et al. 2009-2014).

The most extensive tracts of sandsage prairie are associated with major dune fields and sand areas of the Great Plains (Fig. 1), the largest being the South Platte Dune Field of northeastern Colorado (7500 sq km; 2896 sq mi), the Wray Dune Field of northeastern Colorado and southwestern Nebraska (6680 sq km; 2579 sq mi), and the Black Squirrel Dune Field of east-central Colorado (3570 sq km; 1378 sq mi) (area estimates per Madole 1995). Sandsage prairie is the dominant vegetation of these dune fields.

In the southern part of its geographical range in western Oklahoma and the adjacent upper Texas Panhandle, stands of sandsage prairie occur in mosaic with sand shinnery. Within this transition zone, some areas of the landscape are dominated by sand shinnery with smaller inclusions of Artemisia filifolia while in other areas sandsage prairie dominates. In areas of co-occurrence, sand shinnery mostly occupies higher topographic positions such as hillcrests. In western Oklahoma, elements of Cross Timbers oak woodland vegetation also occur in some of these mosaic communities (Cordova et al. 2005). This area is indicated as Transition Zone South (TZS) in Figure 1.

A second area of transition occurs at the northern limits of the range of sandsage prairie, indicated as Transition Zone North (TZN) in Figure 1. Tracts of sandsage prairie do not occur within the Nebraska 
Sandhills of north-central Nebraska and adjacent South Dakota, but stands of Artemisia filifolia do occur in belts along the edges of the western half of this massive dune field. Kaul \& Rolfsmeier (1993) mapped this vegetation as "Sand Hills borders mixed-grass prairie" to distinguish it from the "Sandsage mixed-grass prairie" of the dune fields of southwestern Nebraska, noting the former combined elements of sand prairie, sandsage prairie, and western Great Plains mixed grass prairie. In eastern Wyoming, stands of Artemisia filifolia sometimes occur in mosaic with shrub-steppe dominated by Artemisia cana, which becomes the prevailing vegetation of well-drained coarse-textured soils in the northern Great Plains (Miller et al. 2011). The physiognomy of Artemisia cana steppe is very similar to that of sandsage prairie with Bouteloua gracilis and Calamovilfa longifolia the co-dominant grasses (Thilenius et al 1995).

Berg (1994) estimated that "sand sagebrush-mixed prairie" covered approximately 12 million acres (5 million hectares) in the Great Plains. This is nearly equivalent to the estimated 12.75 million acres of sand prairie rangeland in the Nebraska Sandhills. Colorado appears to have the most sandsage prairie of any state, estimated at nearly 2 million acres (809,000 hectares) with more than $80 \%$ of this on private lands (Rondeau et al. 2011).

\section{Physiography}

The geographical distribution of sandsage prairie is mostly limited to the High Plains, Colorado Piedmont, and Plains Border sections of the Great Plains Physiographic Province (Fenneman 1931). The High Plains section extends from western Nebraska and southeastern Wyoming into eastern New Mexico and the Texas Panhandle. The surface geology of the High Plains section is influenced by Neogene Period non-marine deposits of the Ogallala Group (Miocene to earliest Pliocene). The Colorado Piedmont and Plains Border sections lie to the west and east (respectively) of the High Plains. The major streams of these regions have excavated into and largely removed the Ogallala deposits of the High Plains, exposing older geological formations beneath. Elevations within the overall distribution of sandsage prairie range from $447 \mathrm{~m}$ (1476 ft) on the east (Cimarron River in Woods County, Oklahoma) to 1690 m (5545 ft.) on the west (Chico Basin in El Paso County, Colorado), but elevations of most occurrences in the heart of the overall distribution range from 915 to $1220 \mathrm{~m}$ (3000-4000 ft).

As noted above, the largest tracts of sandsage prairie are associated with major dune fields and sand areas of the Great Plains (Fig. 1). An extensive literature exists concerning the origin, geomorphology, stratigraphy, and dynamics of Great Plains dune fields (Simonett 1960; Madole 1995; Muhs \& Holliday 1995; Muhs et al. 1996; Cordova et al. 2005; Madole et al. 2005; Schmeisser et al. 2010). The topography of these dune fields is often complex and varies from level plains to low rolling hills with relatively flat crests to choppy sandhills with steep sides. Local relief can range from a few meters to as much as $60 \mathrm{~m}(200 \mathrm{ft})$ and slope from 0 to 60 percent.

In addition to major dune fields, stands of sandsage prairie are associated with relatively flat sandy terraces and benches immediately adjacent to and above riparian channels of streams and creeks. In the White River Badlands of South Dakota, stands of Artemisia filifolia are associated with unique eolian cliff-top sand deposits along escarpment crests (Rawling et al 2003). Relatively small bands of Artemisia filifolia can also be associated with pockets of coarse-textured soils weathered from outcroppings of sandstone bedrock.

\section{Climate}

The climate of the region in which sandsage prairie occurs is essentially the same as that of shortgrass steppe region as described by Pielke $\&$ Doesken (2008) and can be summarized as semi-arid with a strong seasonal cycle, large and rapid temperature changes, frequent and persisting dry weather, winds that are moderate to strong year round, and occasional very vigorous storms. Precipitation is the single most important climatic variable controlling plant community ecology in the western Great Plains.

The average annual total precipitation within the overall distribution of sandsage prairie ranges from 635 $\mathrm{mm}$ (25 in) on the east (Waynoka in Woods County, Oklahoma) to $305 \mathrm{~mm}$ (12 in) on the west (Chico Basin in El Paso County, Colorado), with occurrences in the heart of the overall distribution receiving on average from 381 to $457 \mathrm{~mm}$ (15-18 in) of total annual precipitation. Within these averages, seasonal precipitation 
amounts can and do vary greatly from year to year. At an agricultural research station near Akron in northeastern Colorado, average annual precipitation was $419 \mathrm{~mm}$ (16.5 in) for the period 1908 to 1985, but ranged from a low of $254 \mathrm{~mm}$ (10 in) in 1939 to a high of $686 \mathrm{~mm}$ (27 in) in 1946 (McGinnies et al. 1991). Growing season (April-September) precipitation contributes $70 \%$ to $82 \%$ of the annual moisture across the region (Pielke \& Doesken 2008).

Periodic drought is a recurrent local and regional event throughout the distribution of sandsage prairie. The extended drought of the 1930s hit hardest in the "Dust Bowl" region of the Great Plains, with the most extreme drought occurring in southeastern Colorado the adjacent parts of Kansas, New Mexico, and Oklahoma, and the upper Texas Panhandle (Worster 1979) where significant tracts of sandsage prairie occur. Rondeau et al. (2018) studied the effects of repeated severe drought on grassland communities including sandsage prairie in east-central Colorado, where total annual precipitation in 2002 (< $100 \mathrm{~mm}$; 4in) and 2012 (127 mm; 5 in) was even lower than the driest years of the 1930s. They concluded that Artemisia filifolia may be at the limits of its drought tolerance range in southeastern Colorado, where average annual total precipitation is 305 $\mathrm{mm}$ (12 in).

\section{Soils}

Soils supporting sandsage prairie are mostly formed in sandy eolian parent material and are very deep, excessively drained to well drained, and rapidly to moderately permeable. Soil texture classes range from sand to fine sand to loamy fine sand to fine sandy loam. Sandsage prairie occurs in association with a number of different soil series throughout its distribution in the Great Plains, but northern stands (Nebraska and northeastern Colorado) are strongly associated with Valent series soils (sands) while the Tivoli series (fine sands) is a predominant soil association of southern stands (Kansas, New Mexico, Oklahoma, and Texas).

In habitat supporting sandsage prairie, rainfall infiltrates rapidly and percolates deeply into the coarsetextured sandy soils with little or no runoff. Evaporation quickly dries out the surface sand but only to a slight depth, leaving a layer of dry sand that reduces further evaporation. Below this surface mulch of $2.5-5 \mathrm{~cm}$ (1-2 in), the soil is usually well supplied with moisture (Schantz 1911; Weaver 1919, 1958). As noted by Weaver (1958), "The efficiency of sand in absorbing rainfall without loss by runoff and in almost entirely preventing evaporation is the compensating factor which permits the growth of tall grasses." The generally sparse vegetation of sandsage prairie limits water losses by transpiration, further enhancing the moisture holding capacity of sandy soil. Finally, unlike the fine-textured soils that support shortgrass prairie, soil moisture is not held as tightly in coarse-textured sandy soils. All of these factors enable sandhills habitat to support taller, more mesicadapted grasses like Andropogon hallii and Calamovilfa longifolia in an otherwise semi-arid climate.

In his studies of the root systems of plants in sandhills in east-central Colorado, Weaver (1919) observed that 18 of the 19 species examined had their main root development in the first $60-90 \mathrm{~cm}(2-3 \mathrm{ft})$ and that the roots of eight species were entirely or nearly confined to the first $60 \mathrm{~cm}(2 \mathrm{ft})$, enabling these plants to intercept moisture before it percolates down through the sandy soil. Many of the dominant grasses and forbs of sandsage prairie also occur in the Nebraska Sandhills and diagrams of the root systems of these species show similar morphologies (Tolstead 1942; Weaver 1958; Weaver \& Albertson 1956).

Soil texture and topography are closely related in sandhills habitat, resulting in topoedaphic variability and local topoedaphic patterns that influence plant community structure and composition, primarily through effects on spatial and temporal variation in soil moisture (Barnes et al. 1984). Studies in habitat supporting sandsage prairie have clearly demonstrate the relationship between topoedaphic variability and vegetation structure (Shantz 1911; Ramaley 1939; Hullet et al. 1988; McGinnies et al. 1991; Kelso et al. 2007; Winter et al. 2011a).

\section{FLORISTICS OF SANDSAGE PRAIRIE}

The Appendix provides an enumeration of plant taxa that are characteristic of sandsage prairie in the Great Plains of North America. The list is based on literature review and the author's field experience. It does not include all plants associated with sandsage prairie throughout its range, but those reported or observed to be 
dominant, diagnostic, frequent, or occurring regularly in sandsage prairie. It does not include species that occur in wetlands or other hydric habitat within the context of sandsage prairie vegetation. Exotic species that occur in degraded stands of sandsage prairie (e.g., Bromus tectorum) are also excluded from the list.

The flora of sandsage prairie consists of 119 taxa in 33 families. The largest families represented are Poaceae ( 27 species), Asteraceae (19 species), and Fabaceae (10 species). The next largest families (with six species each) are Euphorbiaceae and Onagraceae. Of the 119 plant taxa occurring in sandsage prairie, 34 (29\%) are annuals, 10 (8\%) biennials (that may also behave as annuals or short-lived perennials depending on environmental conditions), and 75 (63\%) perennials (including four shrubs).

None of these species are strictly limited to sandsage prairie but instead also occur in other areas of sand habitat in the Great Plains, primarily sand prairie in the Nebraska Sandhills and sand shinnery in the southern Great Plains. Twenty-nine species associated with sandsage prairie (24\% of the flora) are endemic to the Central Grassland of North America (Table 3) and four species are considered globally vulnerable to extinction (NatureServe rank of G3)—Chenopodium cycloides, Dalea cylindriceps, Euphorbia carunculata, and Euphorbia strictior.

Two other rare plant species are peripherally associated with sandsage prairie and therefore not included in the Appendix. The recently described Evolvulus arenarius (Harms 2014) is known from at least one occurrence in sandsage prairie (Hartley County, Texas) and is likely a species of conservation concern but has not yet been ranked. A species of dodder, Cuscuta plattensis, is associated with sandhill habitat in southeastern Wyoming where sandsage prairie is likely the dominant vegetation (Handley \& Fertig 2002). Ranked Gl (critically imperiled) by NatureServe, the distribution and ecology of this species need further study.

The total range of sandsage prairie extends approximated $600 \mathrm{~km}(375 \mathrm{mi})$ from north to south (Fig. 1). Many graminoids, forbs, and shrubs are associated with sandsage prairie throughout this area. Others are restricted to or more prevalent in northern versus southern stands (Table 4). Eleven species are most strongly associated with northern stands and have floristic affinities with sand prairie vegetation of the Nebraska Sandhills (Pool 1914; Tolstead 1942; Rolfsmeier \& Steinauer 2010) and dune vegetation in central Wyoming (Knight 1994; Heidel 2012). Twenty-three species are most strongly associated with southern stands and have floristic affinities with sand shinnery vegetation in Oklahoma, Texas, and New Mexico (Dick-Peddie 1993; Peterson \& Boyd 1998; Powell \& Worthington 2018). This north-south floristic gradient was first observed by Daley (1972) in his studies of sandsage prairie in eastern Colorado, with a zone of transition occurring in eastcentral Colorado. Such variation could warrant recognition of a northern and southern expression of sandsage prairie, much as Kuchler (1974) recognized for shortgrass prairie in Kansas.

STRUCTURE OF SANDSAGE PRAIRIE VEGETATION

Describing the structure of sandsage prairie vegetation is challenging. While the most visually conspicuous element in the landscape is shrub-steppe dominated by Artemisia filifolia (Fig. 2), any given occurrence of sandsage prairie is a spatially complex, patchy mosaic of intergrading assemblages of species tied to various degrees of disturbance and stabilization within the dune field. In the literature of sandsage prairie ecology, these assemblages have been referred to as associations (Shantz 1911), communities (Ramaley 1939; Hullett et al. 1988), vegetation types (McGinnies et al. 1991), and vegetation zones (Kelso et al. 2007). These assemblages are recognized here as sub-communities.

\section{The Shrub-Steppe Matrix}

Shrub-steppe dominated by Artemisia filifolia is the primary community of sandsage prairie and provides the matrix by which the sub-communities interface with the vegetation as a whole. It is characteristic of habitat in a late-intermediate stage of stabilization (Fig. 3) and is the equivalent of the "Sand-hills Mixed Association" of Shantz (1911) and the "Sand-Sage Community" of Ramaley (1939). Soils supporting this community have a higher percentage of fine particles than the soils of dune crests, blowouts, and other erosional habitat (Ramaley 1939; Kelso et al. 2007).

Artemisia filifolia is a much-branched shrub that grows $0.5-1 \mathrm{~m}(1.5-3 \mathrm{ft})$ tall and $30-60 \mathrm{~cm}(1-2 \mathrm{ft})$ 
TABLE 3. Central Grassland endemic plants (per Locklear 2017a) that occur in association with sandsage prairie.

$\begin{array}{llll}\text { Argemone polyanthemos } & \text { Dieteria canescens var. nebraskana } & \text { Mentzelia nuda } & \text { Phlox andicola } \\ \text { Asclepias arenaria } & \text { Dimorphocarpa candicans } & \text { Mimosa rupertiana } & \text { Polanisia jamesii } \\ \text { Astragalus ceramicus var. filiformis } & \text { Eriogonum annuum } & \text { Muhlenbergia pungens } & \text { Prunus pumila var. besseyi } \\ \text { Chenopodium cycloides } & \text { Euphorbia carunculata } & \text { Oenothera cinerea var. cinerea } & \text { Redfieldia flexuosa } \\ \text { Croton texensis var. texensis } & \text { Euphorbia strictior } & \text { Oenothera engelmannii } & \text { Yucca glauca } \\ \text { Dalea arenicola } & \text { Hymenopappus flavescens } & \text { Oenothera rhombipetala } & \\ \text { Dalea lanata } & \text { Ipomoea leptophylla } & \text { Oenother serrulata } & \\ \text { Dalea villosa } & \text { Linum berlanderi } & \text { Penstemon buckleyi } & \end{array}$

TABLE 4. Plant species restricted to or most prevalent in northern versus southern stands of sandsage prairie.

\begin{tabular}{lll}
\hline Northern & Southern & Southern (cont) \\
\hline Calamovilfa longifolia & Aphanostephus ramosissimus & Lorandersonia baileyi \\
Carex heliophila & Aristida divaricata & Mimosa rupertiana \\
Cirsium canescens & Calamovilfa gigantea & Oenothera cinerea \\
Dieteria canescens & Dalea lanata & Oenothera engelmannii \\
Eriogonum effusum & Dimorphocarpa candicans & Palafoxia rosea \\
Hesperostipa comata & Euphorbia carunculata & Penstemon buckleyi \\
Muhlenbergia pungens & Euphorbia strictior & Phyllanthus warnockii \\
Prunus pumila var. besseyi & Gaillardia pulchella & Poa arachnifera \\
Penstemon angustifolius & Hedyotis humifusa & Prunus angustifolia \\
Phlox andicola & Hymenopappus flavescens & Psilostrophe villosa \\
Physaria ludoviciana & Indigofera miniata & Sporobolus giganteus \\
& & \\
\hline
\end{tabular}

across. The gray-green foliage is aromatic and individual leaves are long and slender (to $40 \times 0.5 \mathrm{~mm}$ ) and divided into threadlike segments. A diagram in Weaver's 1919 paper on the ecological relations of roots (reprinted in Grasslands of the Great Plains [Weaver \& Albertson 1956]) shows the root system of a ten-year-old

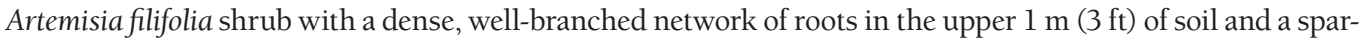
ingly branched taproot extending $2.4 \mathrm{~m}(8 \mathrm{ft})$ below the surface, a morphology that both anchors the plant in the dynamic dune habitat and helps intercept moisture before it percolates down through the sandy soil.

There is no recognized standard for the amount or density of Artemisia filifolia canopy cover in the landscape that delineates vegetation as sandsage prairie. Ramaley (1939) observed about $10 \%$ canopy coverage by Artemisia filifolia in a large tract ("a number of square miles") of what he considered a "typical" sandsage community. In Nebraska, Rolfsmeier and Steinauer (2010) distinguished sandsage prairie as "any community in which sandsage represents a conspicuous part ( $>5 \%$ cover)." Vegetation classification systems for Kansas (Lauver et al. 1999) and Oklahoma (Hoagland 2000) treat sandsage prairie as a type of shrubland where Artemisia filifolia forms $>25 \%$ canopy cover. In a 20 year study of the impacts of grazing intensity and precipitation in western Oklahoma sandsage prairie the average canopy cover of Artemisia filifolia was 38\% (Gillen \& Sims 2004).

In reality, the density of Artemisia filifolia in the landscape is influenced by a host of factors. In their study of sandsage prairie in southwestern Kansas, Hulett et al. (1988) found percent canopy cover by Artemisia filifolia differed along a topographic gradient, with $10 \%$ cover on "level sands," $21 \%$ on "dune sands," and $34 \%$ on "choppy sands." The relative density of Artemisia filifolia is also subject to climatic influences, fire history, and past rangeland management practices. These disturbance factors are discussed under Vegetation Dynamics.

The graminoid component of sandsage prairie typically has a canopy of taller grasses (1-2 m; 3-6 ft) intermixed with mid-height grasses $(0.5-1 \mathrm{~m} ; 1.5-3 \mathrm{ft})$ with an underlayer of short grasses and sedges. Grasses reported as principal components of sandsage prairie throughout the Great Plains are Andropogon hallii, Sporobolus cryptandrus, Schizachyrium scoparium, and Bouteloua gracilis, each of which have been recognized as co-dominant with Artemisia filifiolia in a particular part of the overall range of sandsage prairie (Table 5). 


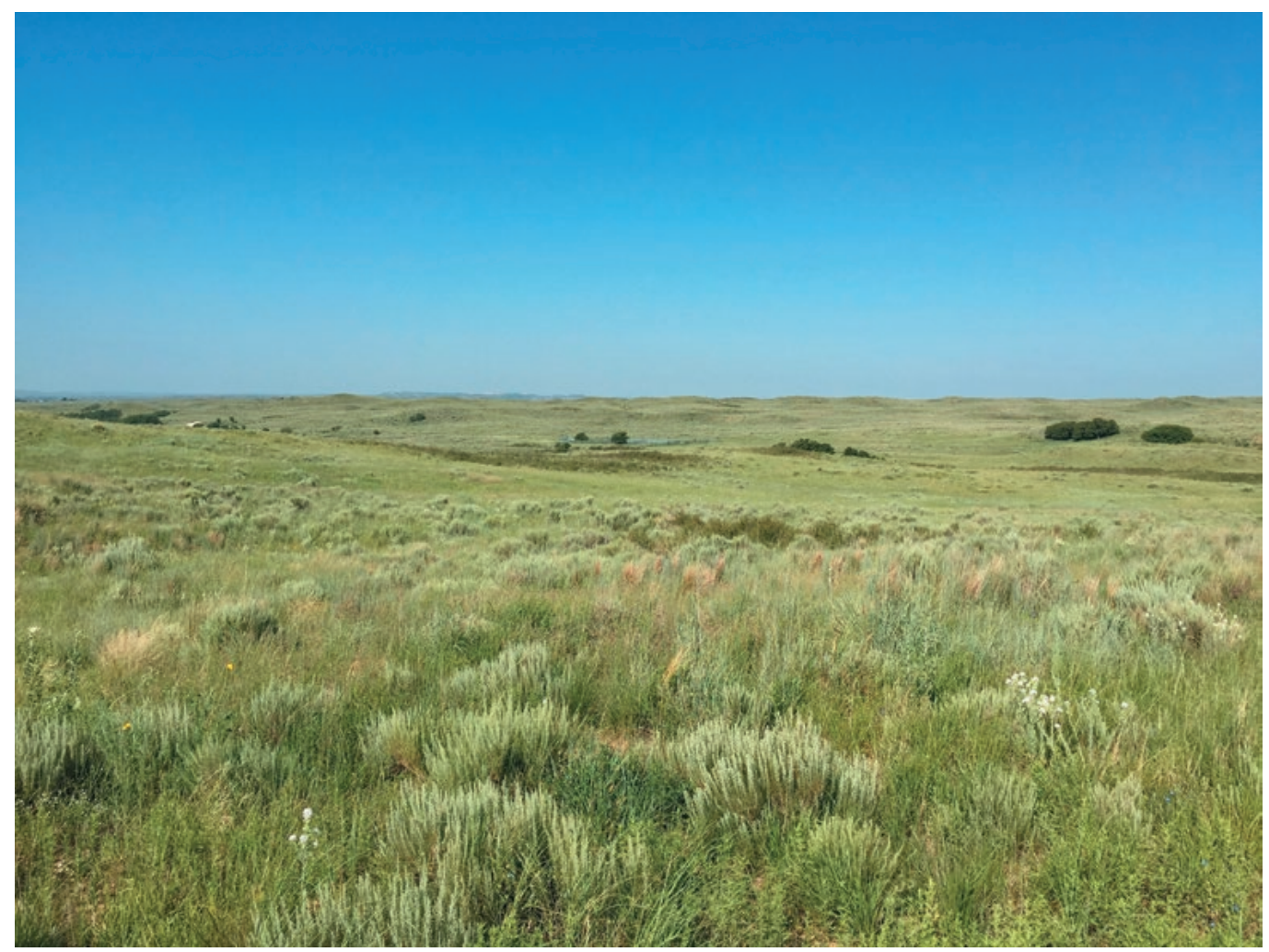

FIG. 2. Sandsage prairie, Hemphill County, Texas. Photo James H. Locklear.

Other widely occurring regular graminoid associates of sandsage prairie include Aristida purpurea, Bouteloua hirsuta, Cyperus schweinitzii, Elymus elymoides, Eragrostis trichodes, and Vulpia octoflora.

A number of other graminoids are of regional importance in sandsage prairie (Table 4). The cool-season Hesperostipa comata and Carex heliophila are major species in northern stands of sandsage prairie (northeastern Colorado and southwestern Nebraska) but diminish in importance to the south. The warm season grass Calamovilfa longifolia is a major species in northern stands but absent from southern stands where it is replaced by Calamovilfa gigantea.

Several variants of sandsage prairie have been recognized and distinguished by one or more co-dominant grass species (Table 5). Such descriptions of the diagnostic graminoid component of sandsage prairie should be qualified with the observation that the constituent species and their relative dominance can change locally over time due to year-to-year trends in precipitation and grazing history.

Similar to the graminoid component, many forbs are associated with sandsage prairie throughout the Great Plains while others are more regionally restricted (Table 4). Widespread sandsage prairie forbs include Abronia fragrans, Commelina erecta, Croton texensis, Dalea villosa, Erigeron bellidiastrum, Eriogonum annuum, Helianthus petiolaris, Ipomoea leptophylla, Ipomopsis longifolia, Mentzelia nuda, Oenothera serrulata, Palafoxia sphacelata, Penstemon ambiguus, and Tradescantia occidentalis. Southern stands of sandsage prairie have a greater diversity of forbs than do northern stands (Table 4).

A few shrubs are consistent components of sandsage prairie. Yucca glauca and Rhus aromatica var. trilobata occur throughout the range of sandsage prairie and in some occurrences are so abundant as to 


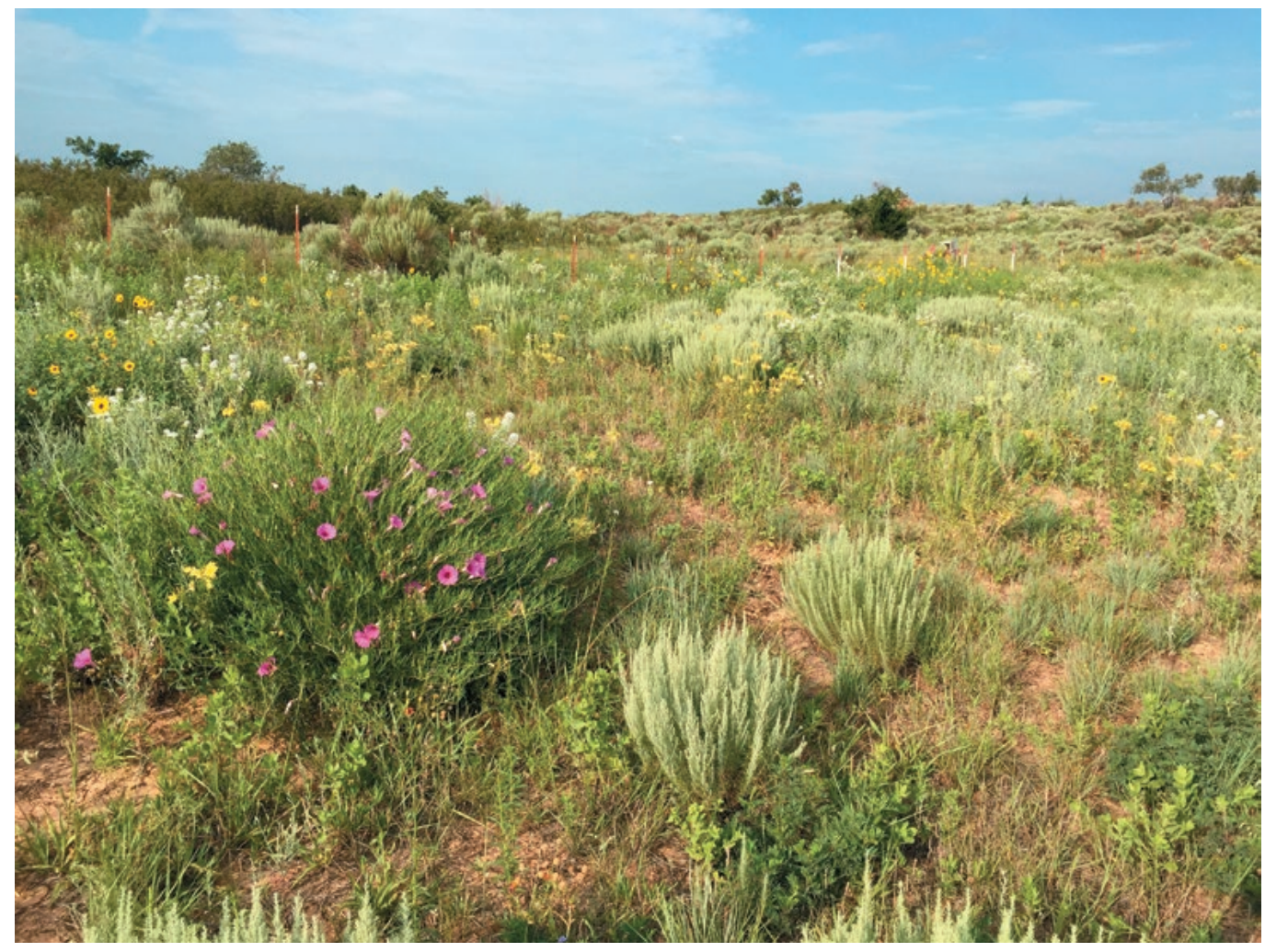

FIG. 3. Sandsage prairie, Woodward County, Oklahoma. Prominent forbs include Dimorphocarpa candicans, Helianthus petiolaris, Ipomoea leptophylla, and Oenothera rhombipetala. Photo James H. Locklear.

co-dominate the shrub stratum. Prunus pumila var. besseyi is more prevalent in northern stands while Prunus angustifolia is limited to southern stands.

\section{Open Sand and Blowout Sub-Community}

A dune complex supporting sandsage prairie may have areas of highly disturbed habitat with open sand and little or no vegetation. Such habitat typically occurs on the crests and upper windward slopes of taller and steeper dunes. The most eroded sites are called blowouts, where sand is actively moving and there is little or no vegetation present. This habitat supports the Open Sand and Blowout sub-community, which is the equivalent of the "Blow-out Association" of Shantz (1911) and the "Loose Sand and Blow-Out Community" of Ramaley (1939).

Blowouts are irregular or conical craters formed when deep, loose sands are removed by swirling wind action of the prevailing winds, the sand carried from the windward side of the slope and deposited onto the leeward side (Fig. 4). The formation of blowouts has been well documented in the Nebraska Sandhills and the progression of species involved in re-vegetation of blowouts in northern stands of sandsage prairie is very similar to that observed in the Nebraska Sandhills (Rydberg 1895; Pound \& Clements 1900; Pool 1914; Tolstead 1942; Stubbendieck et al. 1989). The size of blowouts in dune fields supporting sandsage prairie ranges from less than $15 \mathrm{~m}(50 \mathrm{ft})$ to over $600 \mathrm{~m}(2000 \mathrm{ft})$ in diameter and from a meter or two to as much as $30 \mathrm{~m}(100 \mathrm{ft})$ in depth (McGinnies et al. 1991).

Shantz was the first to describe blowouts in the context of sandsage prairie. Based on his observations in 
TABLE 5. Recognized Artemisia filifolia associations in the Great Plains (per NatureServe unless noted).

Artemisia filifolia / Andropogon hallii

Artemisia filifolia / Bouteloua (curtipendula, gracilis)

Artemisia filifolia / Calamovilfa longifolia

Artemisia filifolia / Schizachyrium scoparium - Andropogon hallii

Artemisia filifolia / Sporobolus cryptandrus

Artemisia filifolia / Sporobolus cryptandrus - Schizachryium scoparium (Hoagland 2000)

Artemisia filifolia / Rhus trilobata

Artemisia filifolia / Yucca glauca (Shaw et al. 1989)

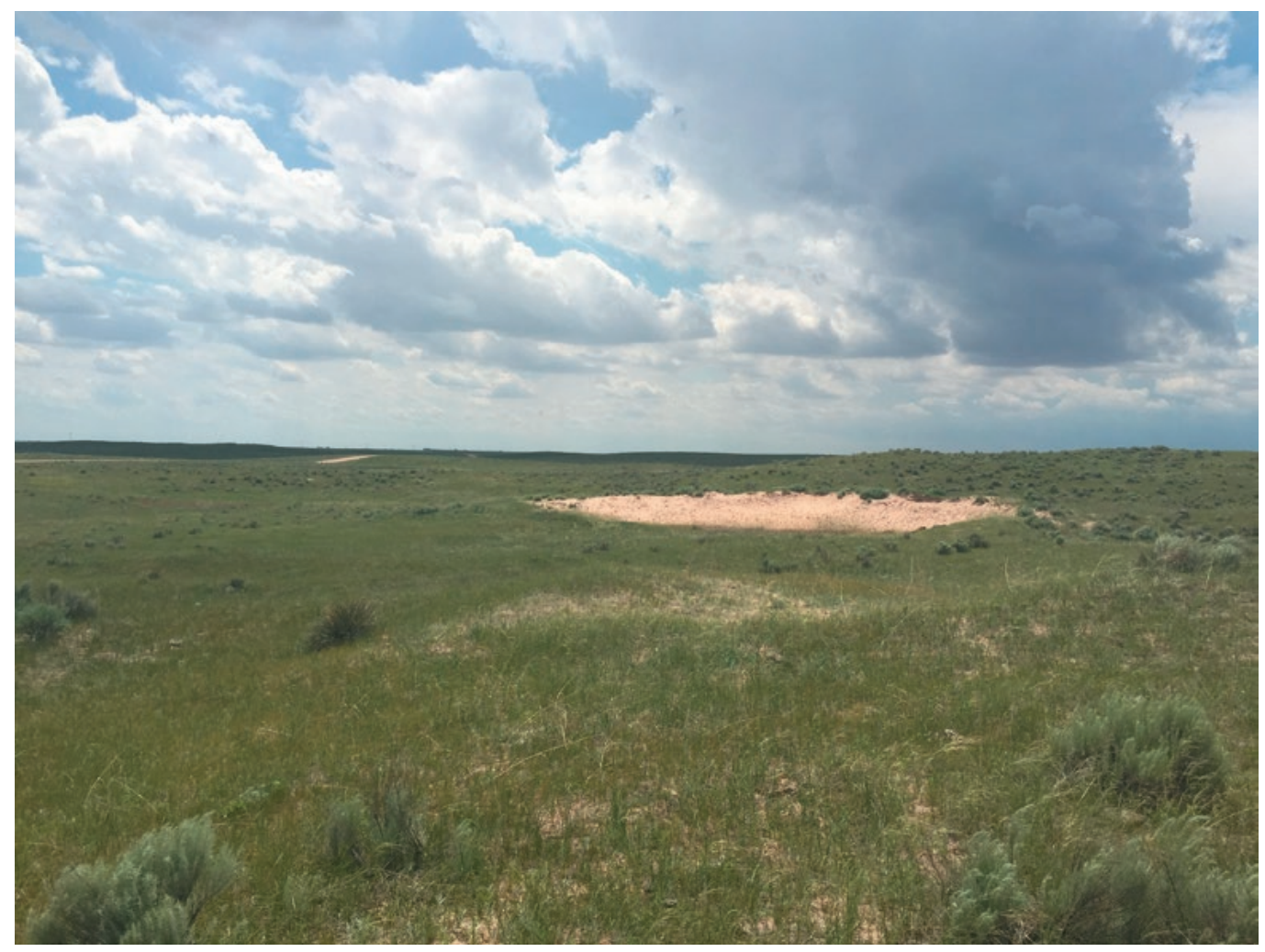

FIG. 4. Blowout in sandsage prairie, Perkins County, Nebraska. Photo James H. Locklear.

the Wray Dune Field in northeastern Colorado, he identified Redfieldia flexuosa, Psoralidium lanceolatum, Muhlenbergia pungens, and Dalea villosa as the most important plants of his "Blow-Out Association." The pioneering role of Redfieldia flexuosa, Psoralidium lanceolatum, and Muhlenbergia pungens, all herbaceous perennials, has been noted in other studies of sandsage prairie in eastern Colorado (Weaver 1919, Ramaley 1939, Kelso et al. 2007), with Stipa hymnenoides also being important. A number of small annuals typically proceed or accompany these perennials as early invaders of open sand including Heliotropium colvolvulaceum, Polanisia dodecandra subsp. trachysperma, and Polanisia jamesii. Perennial forbs of secondary importance include Astragalus ceramicus var. filifolius and Oenothera latifolia.

Thanks to the ground-breaking work of Shantz, a detailed description of the ecology of blowouts in sandsage prairie is provided in the U. S. Department of Agriculture report, Changes in Vegetation and Land Use in 
Eastern Colorado: A Photographic Study, 1904-1986 (McGinnies et al. 1991). Shantz took photographs of vegetation in eastern Colorado from 1907-1914, then re-photographed the same sites in the 1940s and 1950s to document the impact of the great drought of the 1930s. Healso recorded the species composition of the photographed sites. Shantz's photographs and notes were not published but following his death in 1958 were archived in the University of Arizona Herbarium. W.J. and W.G McGinnies visited Shantz's photo points in 1985 and 1986 and again took photographs of the vegetation and landscape. These series of photographs and associated notes are published in their report and provide strong visual documentation of the process of re-vegetation.

Shantz made photographic studies of several blowouts in the Wray Dune Field near Yuma, Colorado between 1909 and 1914. He identified six stages in the succession of species that re-vegetated blowouts. His stages and the primary associated species associated with each stage were published in McGinnies et al (1991) and are presented in Table 6.

Dune fields with actively moving sand occur in the context of sandsage prairie in western Oklahoma and the upper Texas Panhandle. The most well-known of these is the Little Sahara dunes associated with the Cimarron River in Woods County, Oklahoma. The earliest of the pioneer species of open sand habitat here are annuals including Heliotropium convolvulaceum, Phyllanthus warnockii, and Polanisia jamesii (Sherwood \& Risser 1980) (Fig. 5), and the rare species Euphorbia carunculata (Waterfall 1948). As in northern stands of sandsage prairie, Redfieldia flexuosa and Psoralidium lanceolatum are the first perennials to colonize this open habitat.

\section{Stabilizing Dune Sub-Community}

Following the initial invasion of a blowout or area of open sand by annuals and pioneering perennials, a secondary suite of species begins to occupy the partially stabilized habitat. In northern and, to a lesser extent, central stands of sandsage prairie, this stage is dominated by Muhlenbergia pungens. In southern stands, Calamovilfa gigantea is the most prevalent species of partially stabilized habitat.

Although these two grasses have very different growth habits, they play similar roles in stabilizing actively eroding habitat, particularly in choppy dunes and other areas of high relief. Muhlenbergia pungens is a tufted, wiry grass that spreads by rhizomes and forms matted clumps $20-50 \mathrm{~cm}(8-20 \mathrm{in})$ tall. In older plants, the central part of the mat often dies out leaving an open ring or crescent that catches blowing sand and holds it in place, further stabilizing sandy habitat. Calamovilfa gigantea is an ascending species of relatively few stout culms that may reach up to $2.5 \mathrm{~m}(8 \mathrm{ft})$ in height and binds sandy soil by a dense network of roots and spreading rhizomes.

Occurrences of this sub-community in northern parts of the range of sandsage prairie are the equivalent of the "Sand-Hills-Mixed Community" of Ramaley (1939) which he described as being dominated by clumps of Muhlenbergia pungens and intermediate between blowout and sandsage communities (Fig. 6). Pool (1914) recognized a similar "Muhlenbergia Association" in the Nebraska Sandhills.

This sub-community hosts the highest level of plant species diversity within the overall structure of sandsage prairie vegetation (Schantz 1911; Kelso et al. 2007). A number of forbs are especially characteristic of partially stabilized habitat throughout the range of sandsage prairie, including Asclepias arenaria (Fig. 7), Dalea villosa, Erigeron bellidiastrum, Helianthus petiolaris, Ipomopsis longiflora, Mentzelia nuda, Palafoxia sphacelata, Penstemon ambiguus, and Physalis hispida. A degree of geographic differentiation occurs in this stage of habitat stabilization, with Phlox andicola limited to northern stands and Dalea lanata, Indigofera miniata, and Stillingia sylvatica in southern stands.

As vegetation cover increases and the dune habitat becomes more stabilized, this sub-community typically transitions to Artemisia filifolia steppe.

\section{Prairie Inclusion Sub-Community}

Within dune fields supporting sandsage prairie are areas of relatively low relief or, in more complex terrain, zones of protected habitat such as the lower leeward slopes of dunes and interdunal swales, flats, or "slacks." The soils of such sites are well-drained fine sands and loamy fine sands in contrast to the more coarse-textured 
TABLE 6. Stages in the re-vegetation of blowouts in the Wray Dune Field, Colorado (McGinnes et al 1991).

Stage 1 Open sand except for occasional annuals (Helianthus petiolaris, Polanisia dodecandra subsp. trachysperma)

Stage 2 Redfieldia flexuosa, Psoralidium lanceolatum

Stage 3 Muhlenbergia pungens, Redfieldia flexuosa, Psoralidium lanceolatum, Andropogon hallii

Stage 4 Andropogon hallii, Psoralidium lanceolatum, Muhlenbergia pungens, Redfieldia flexuosa

Stage 5 Andropogon hallii, Schizachyrium scoparium, Muhlenbergia pungens

Stage 6 Semi-stable Schizachyrium scoparium vegetation type

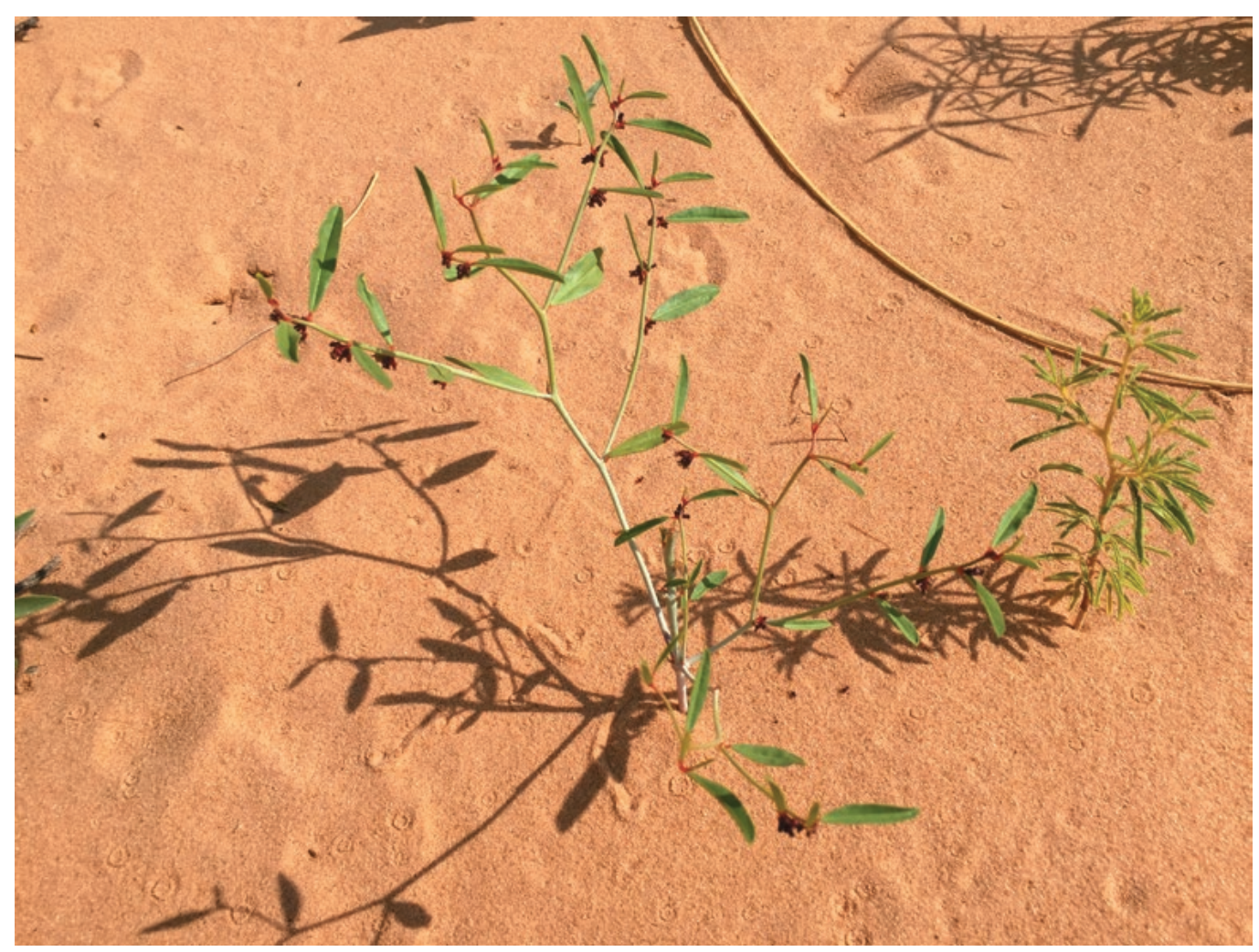

FIG. 5. Annual forbs Phyllanthus warnockii and Polanisia jamesii in open sand habitat, Woodward County, Oklahoma. Photo James H. Locklear.

soils of the upper slopes of dunes. This habitat often supports a grass-dominated vegetation in which the shrub component of Artemisia filifolia is lacking or significantly reduced. This sub-community is the equivalent of the "Sand Prairie Community" of Ramaley (1939) and typically occurs in relatively small patches or inclusions within the overall context of sandsage prairie.

In northeastern Colorado, this sub-community is dominated by Andropogon hallii, Calamovilfa longifolia, and Hesperostipa comata (Ramaley 1939), a floristic composition similar to that of grassland covering millions of hectares of uplands in the Nebraska Sandhills (Rolfsmeier \& Steinauer 2010). Other examples include leeward slopes and interdunal swales in east-central Colorado sandsage prairie with Andropogon hallii, Stipa hymenoides, Sporobolus giganteus, and Sporobolus cryptandrus the most important species (Kelso et al. 2007) and "level sands" in southwestern Kansas sandsage prairie dominated by Bouteloua gracilis, with Calamovilfa 


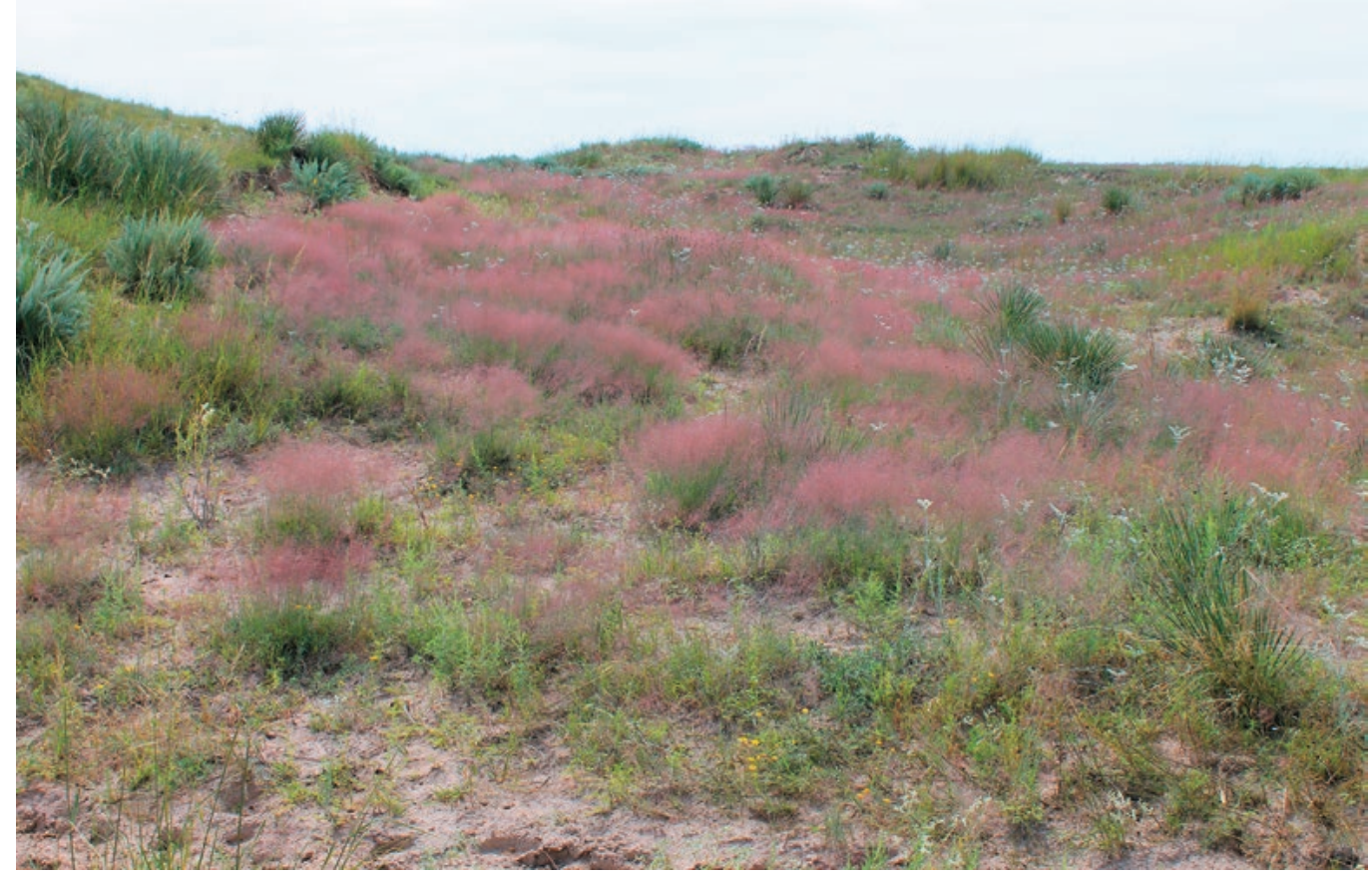

FIG. 6. Stabilizing dune sub-community dominated by Muhlenbergia pungens, Dundy County, Nebraska. Photo James H. Locklear.

longifolia and Sporobolus cryptandrus also important (Hulett et al. 1988). The forb component is often similar to that of the surrounding shortgrass or mixed grass prairie.

Two grass-dominated associations described by Schantz (1911) as occurring in the context of Colorado sandsage prairie are now greatly diminished in extent and may be of conservation concern. First is a Schizachyrium scoparium-dominated "Bunch-Grass Association" that interfaced with his "Sand-Hills Mixed Association" of which Artemisia filifolia was an important element. Schantz observed that the former occurred on "stable sands" and the latter on "unstable sands." He described the Schizachyrium scoparium type as "the most extensive association on the sand hills of eastern Colorado," but follow up research in Shantz's study region found this vegetation had all but disappeared, presumably due to a shift toward a drier climate in the region, recurrent severe droughts, overgrazing, and conversion to cropland (McGinnies et al. 1991). Schizachyrium scoparium still dominates mixed grass prairie on loess soils in northwestern Kansas, southwestern Nebraska, and northeastern Colorado (Hulett et al. 1968; Rolfsmeier \& Steinauer 2010), but extensive stands seem to have been eliminated from sandhills habitat in the region.

Shantz also identified a variant of shortgrass prairie dominated by Aristida purpurea (his "Wire-Grass Association") that occurred on sandy loam soils in areas of transition between and the Schizachyrium scoparium-dominated Bunch-Grass Association of sandhills and the Bouteloua gracilis - Buchloe dactyloides shortgrass prairie on clay-loam "hard lands." Follow up research likewise found that very little of this association remained in eastern Colorado "because most of it has been plowed and planted to wheat" (McGinnies et al. 1991). Vegetation resembling this association was recently observed in southwestern Nebraska in the context of sandsage prairie rangeland (Locklear 2017b).

\section{Wetland Sub-Community}

Wetlands and even small lakes were once common features of dune fields supporting sandsage prairie. These 


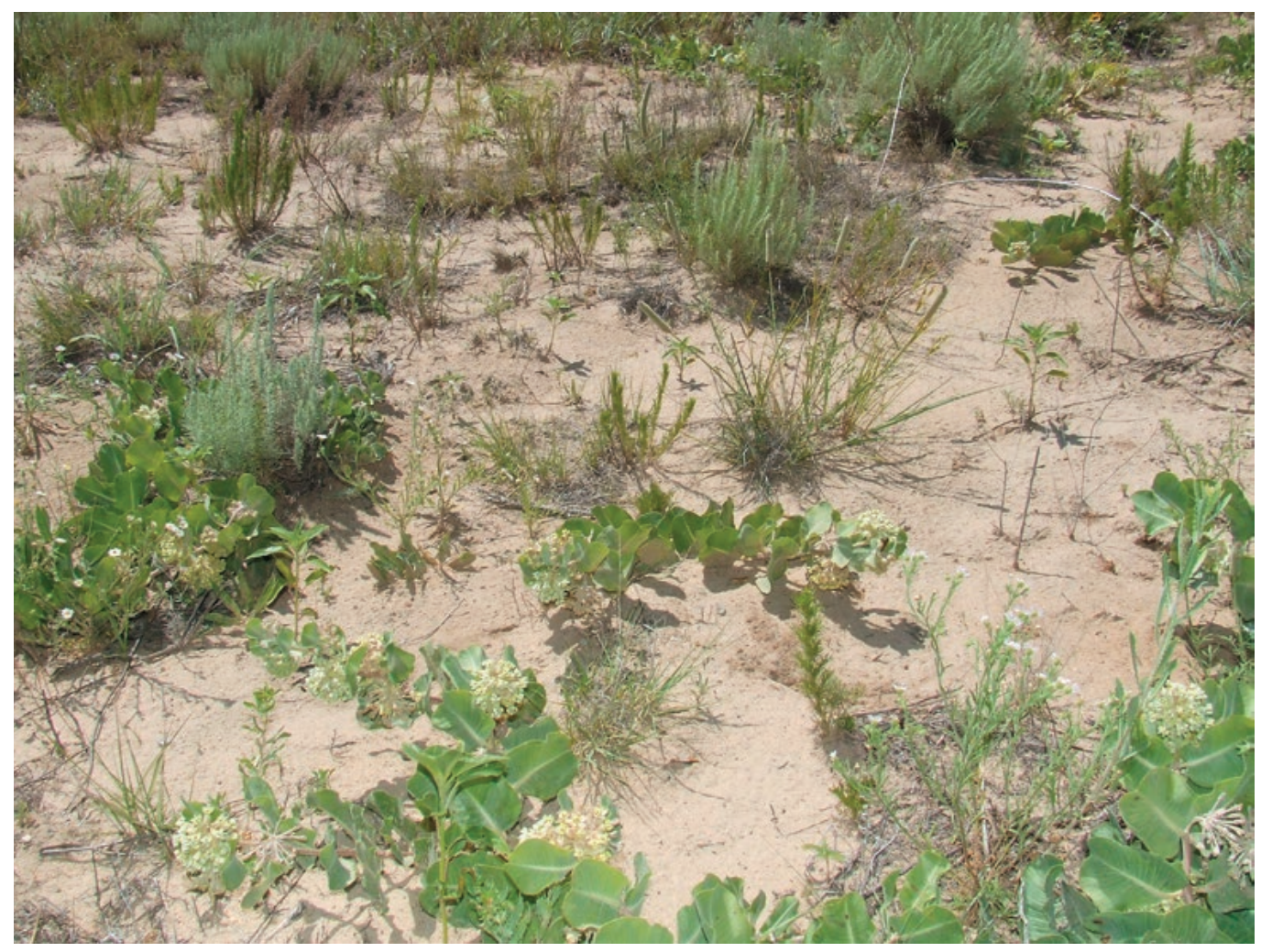

FIG. 7. Stabilizing dune sub-community, Cheyenne County, Colorado. Prominent forbs include Asclepias arenaria and Dalea cylindriceps. Photo James H. Locklear

occurred in interdunal valleys, swales, and depressions where the water table was close to the surface, and along riparian corridors of intermittent streams (Ramaley 1939; Hullett et al. 1988; Farrar 1993a, 1993b; Neid et al. 2007). Such areas have largely disappeared due to depletion of the regional aquifers by irrigation for crop production but historically supported a mosaic of aquatic communities and subirrigated meadow-like vegetation dominated by graminoids like Elymus smithii and Panicum virgatum.

\section{VEGETATION DYNAMICS}

Sandsage prairie occurs in highly dynamic habitat subject to a host of natural disturbance factors, most notably periodic and often severe drought, fire, and herbivory. The independent effects of any one of these factors on community structure can be and often is intensified by interaction with others, such as fire followed by drought. As a consequence, there is a high level of heterogeneity in the structure of sandsage prairie vegetation with frequent shifts in species composition and dominance, not only within the Artemisia filifolia steppe component of the vegetation, but also within and between the constituent sub-communities.

In a study of vegetation dynamics of sandsage prairie in western Oklahoma over a 39-year period (1940 to 1978), Collins et al. (1987) observed patterns of increase and decrease at the species level that could be attributed to both fluctuation (a reversible change in dominance within a stable species assemblage) and succession (a more or less directional change in composition and/or dominance). Their results imply that a given stand of sandsage prairie is in dynamic equilibrium with the local environment.

That sandsage prairie is a dynamic plant community is evidenced in the life history traits of the 
constituent plant species. As noted above, $29 \%$ of the plant taxa associated with sandsage prairie are native annuals and another $10 \%$ behave as annuals, biennials, or short-lived perennials depending on environmental conditions. This compares to $21 \%$ native annuals in the flora of shortgrass prairie in northeastern Colorado (Hazlett 1998). Relatively high percentage of annuals in a flora is characteristic of plant communities subject to periodic natural disturbances such as drought-stressed rock outcrop environments in the southeastern United States (28\% annuals per Baskin \& Baskin 1985) and gopher-disturbed xeric sandylands on the Texas Gulf Coastal Plain (70\% annuals per Schaal \& Leverich 1982).

Plants associated with such habitats often exhibit a "fugitive" life history (Platt 1975) adapted to recurring cycles of vegetation disturbance and recovery. In the case of sandsage prairie, annuals like Heliotropium convolvulaceum and Polanisia jamesii are adapted to quickly exploit disturbed habitats like blowouts and persist in a soil seed bank when competition from other plants increases. Perennial forbs that occur in relatively dynamic habitat within sandsage prairie are often monocarpic like Cirsium canescens (Kaul et al. 2011) or polycarpic but short-lived like Dalea cylindriceps (Locklear 2013) and Mentzelia nuda (Keeler 1987).

\section{Response to Drought}

The relative density of Artemisia filifolia in a stand of sandsage prairie is subject to climatic influences, and declines in density due to periodic drought have been documented in eastern Colorado (Rondeau et al. 2018) and western Oklahoma (Gillen \& Sims 2006). Analysis of data gathered over a 39-year period (1940-1978) in western Oklahoma sandsage prairie showed Artemisia filifolia cover fluctuating between 20\% and 50\% during this time, presumably in response to variation in annual precipitation (Collins et al. 1987).

Artemisia filifolia appears to respond relatively quickly to variability in annual precipitation. Vegetation studies in east-central Colorado found average canopy cover of Artemisia filifolia increased over $50 \%$ between 1998 and 1999 in response to 14\% above average precipitation but decreased over 80\% between 2001 and 2002 in response to annual precipitation 68\% less than average (Rondeau 2003, 2013).

Review of accounts published by early explorers of the Great Plains led Muhs and Holliday (1995) to conclude that, although at present mostly stabilized by vegetation, at least parts of dune fields in Colorado, Kansas, Nebraska, New Mexico, and Texas were active in the nineteenth century. While modern observations indicate sandsage prairie is fairly resilient to the effects of drought in the Great Plains, there are biological limits to the ability of this vegetation to tolerate prolonged episodes of severe drought (Rondeau et al. 2018).

\section{Response to Fire}

Range management studies in western Oklahoma have demonstrated that Artemisia filifolia is "highly tolerant to the effects of fire" (Winter et al. 2011b) and "resprouts profusely following fall and spring burns, seemingly without any negative effects on carbohydrate reserves" (Vermeire et al. 2001). This ability to survive and resprout after fire is unique among the shrubby sagebrushes (genus Artemisia), with the exception of Artemisia cana (White \& Currie 1983) which, as noted above, forms a similar shrub-steppe vegetation in sandy habitat in the northern Great Plains.

Information about the historical role of fire in the ecology of sandsage prairie is limited, but wildfire was not uncommon in the southern part of its range. In the 1930s, A.S. Jackson undertook research on wildlife in western Texas at the time of Euro-American settlement in which he conducted interviews of early settlers and reviewed personal diaries, journals, and newspapers of the time. "The picture that emerged," he wrote in 1965, "was one of one of incredibly abundant wildlife in an environment which seemed to be on fire, somewhere, all of the time [italics added]."

Several of Jackson's examples come from areas in the upper Texas Panhandle where sandsage prairie is a significant part of the landscape. He cited observations of Haley (1954) in his book on the history of the XIT Ranch, a cattle ranch in the Texas Panhandle that ran for 300 km (200 mi.) along the border with New Mexico and encompassed over 12,000 sq km (3 million acres) of land. Haley describes several great grass fires from the area, which included large tracts of sandsage prairie. A fire in 1885 that broke out around the Arkansas River near the Colorado-Kansas state line, swept south across the Cimarron River into the northwest part of the Texas Panhandle where it consumed "nearly a million acres of grass." Another fire in 1887, "traveled sixteen 
and one-half miles in about two hours. When it struck the sagegrass in the sand country of the western Panhandle, flames shot high into the air, where the wind caught their tips and hurled them back to the ground to set fire to the grass as much as sixteen feet ahead of the burning portions." By "sagegrass," Haley appears to be referring to Schizachyrium scoparium, which he describes elsewhere as being "rusty" in color at maturity.

Studies by Winter et al. (2012) in Oklahoma sandsage prairie demonstrated this vegetation is resilient to the interactive effects of prescribed fire and grazing and that "land managers can readily alter vegetation structure in A. filifolia shrublands by restoring the fire-grazing interaction." Their research also suggested that forbs in sandsage prairie compete with grasses for resources and that the interaction of fire and grazing allows forbs a period of release from such competition. The historical frequency of wildfire in sandsage prairie is a matter of speculation, but it may have been 5-10 years (Doxon et al. 2011).

\section{Response to Herbivory}

Herbivory is an important factor in the ecology of grassland ecosystems, particularly as it shapes plant community structure and composition (Milchunas et al. 2008). The impacts of herbivory on sandsage prairie are evidenced primarily in the herbaceous component of the vegetation.

The shrub Artemisia filifolia is consumed in relatively small quantities by only a few significant herbivores, notably pronghorn antelope (Anthocarpa americana) (Koerth et al. 1984), mule deer (Odocoileus hemionus) (Sowell et al. 1985), and black-tailed jackrabbits (Lepus californicus) (Sparks 1968). Browsing of Artemisia filifolia by these mammals would have little to no effect on the structure and composition of sandsage prairie.

The most significant impacts of herbivory in sandsage prairie come through grazing of the graminoid and forb components of the vegetation by large ungulates, currently domestic cattle and presumably bison (Bison bison) in the past. No documentation has been found that describes how bison interacted with sandsage prairie prior the elimination of massive herds of this herbivore from the Great Plains by the late 1870s, but observations of bison grazing in the Nebraska Sandhills suggests they would have been attracted to the major grasses of sandsage prairie, notably Andropogon hallii, Calamovilfa longifolia, and Hesperostipa comata, and not deterred by dune topography and sandy soils. Tracts of sandsage prairie would have provided "islands" of these taller grasses in a landscape dominated by shortgrass prairie.

Shantz appears to be the first researcher to comment on the impact of cattle grazing on sandsage prairie, noting in 1911 that cattle had altered stands in eastern Colorado by consuming the major tall grasses Andropogon hallii and Calamovilfa longifolia, resulting in less competition for Artemisia filifolia, which grew into "unusually large plants" under these conditions. While not quantified, his observations are noteworthy since significant stocking of cattle in the region did not begin until the 1880s (Wishart 2013), indicating the reduction/elimination of these grasses occurred in less than 30 years.

Numerous studies have investigated the impacts of cattle grazing intensity or stocking rate on the structure of sandsage prairie, most with a view towards maximizing or at least sustaining forage production for cattle. The operating assumption has been that sandsage prairie can be overgrazed and reduction of competition from the grass and forb component will result in an increase in canopy cover by Artemisia filifolia, which will in turn suppress recruitment and growth of herbaceous plants. Long-term studies in western Oklahoma sandsage prairie (20-year time span, Gillen \& Sims 2006; 50-year time span, Sims et al. 1995) that show that while differences in grazing intensity can alter the relative abundance of particular grasses and forbs in some years, stocking rate does not significantly affect canopy cover of Artemisia filifolia nor produce marked differences in ecosystem function, particularly when compared to weather impacts.

Other impacts are more subtle. A study of the influence of Artemisia filifolia on herbage production of Hesperostipa comata in eastern Colorado sandsage prairie found that the shrub afforded protection for the grass from grazing, which outweighed the effects on biomass (Davis \& Bonham 1979). Another study in Colorado sandsage prairie found increased grazing pressure caused a decline in Hesperostipa comata and Calamovilfa longifolia and an increase in Bouteloua gracilis (Sims et al. 1976). 


\section{CONCLUSION}

Nebraska writer Jon Farrar (1993b) referred to the sandsage prairie region of the southwestern part of the state as the "Cinderella Sandhills," always in the shadow of the grand Nebraska Sandhills to the north. Certainly, sandsage prairie has been one of the most poorly understood and least appreciated ecological systems in the Great Plains. The research presented in this paper was undertaken to address this knowledge deficit and lay the groundwork for improved management, conservation, and restoration of sandsage prairie. A forthcoming paper (Locklear, in prep.) will present the biodiversity values and ecosystem processes and functions supported by sandsage prairie.

\section{APPENDIX}

Annotated list of plant taxa associated with sandsage prairie.

The following compilation enumerates plant taxa that are characteristic of sandsage prairie in the Great Plains, USA. Families are arranged alphabetically within major groups. Taxa are listed alphabetically within their respective families by genus, species, and infraspecific epithet. Synonyms or misapplied names from important early literature are provided in brackets. Life history traits are indicated: Annual (A); Biennial (B); Perennial (P). Taxa with pronounced geographic affinities are noted as Northern ( $\uparrow$ ) or Southern $(\downarrow)$.

\section{ANGIOSPERMS: MONOCOTS}

\section{AGAVACEAE}

Yucca glauca Nutt., YUCCA P

\section{COMMELINACEAE}

COmmelina erecta L., DAYFLOWER P

Tradescantia occidentalis (Britton) Smyth, WESTERN SPIDERWORT P

\section{CYPERACEAE}

Carex heliophila Mack. [Carex inops L.H. Bailey subsp. heliophila] (Mack.) Crins], sUN SEDGE $\mathrm{P} \uparrow$

Cyperus schweinitzii Torr., SCHweInItz's FLATSEDGE $P$

\section{POACEAE}

Andropogon hallii Hack, SAND BLUESTEM P

Aristida divaricata Humb. \& Bonpl. ex Willd., POVERTY THREE-AWN P $\downarrow$ Aristida purpurea Nutt. [A. longiseta Steud.], PURPLE THREE-AWN P Boutelous curtipendula (Michx.) Torr., SIDEOATS GRAMA P

Bouteloua gracilis (Kunth) Lag., BLUE GRAMA P

Bouteloua hirsuta Lag., HAIRY GRAMA P

Calamovilfa gigantea Schrib. \& Merr., GIANT SANDREED P $\downarrow$

Calamovilfa longifolia (Hook.) Scrib., PRAIRIE SANDREED P $\uparrow$

Chloris verticillata Nutt., WINDMILL GRASS $P$

Elymus elymoides (Raf.) Swezey [Sitanion hystrix (Nutt.) J.G. Smith], SQUIRRELTAIL P

Elymus smithii (Rydb.) Gould [Agropyron smithii Rydb.; Pascopyrum smithii (Rydb.) Barkworth \& D.R. Dewey], weSteRn WHEATGRAsS P
Eragrostis secundiflora J. Presl subsp. oxylepis (Torr.) S.D. Koch [E. oxylepis (Torr.) Torr.], RED LOVEGRASS P

Eragrostis trichodes (Nutt.) A.W. Wood, SAND LovEGRASS P

Hesperostipa comata (Trin. \& Rupr.) Barkworth [Stipa comata Trin. \& Rupr.], NEEDLE AND THREAD $P \uparrow$

Koeleria macrantha (Ledeb.) Schult. [K. cristata (L.) Pers.], JunEGrass P Redfieldia flexuosa (Thurb.) Vasey [Muhlenbergia ammophila P.M. Peterson], BLOWOUT GRASS P

Muhlenbergia pungens Thurb. ex A. Gray, SANDHILL MUHLY P $\uparrow$

Munroa squarrosa (Nutt.) Torr., FALSE BUfFALOGRASS A

Panicum virgatum $L$., SWITCHGRASS $P$

Paspalum setaceum Michx. [P. setaceum Michx. var. stramineum (Nash) D.J. Banks; P. stramineum Nash], SAND PASPALUM P

Poa arachnifera Torr., TEXAS BLUEGRASS $P \downarrow$

Schizachyrium scoparium (Michx.) Nash [Andropogon scoparius MichX.], LITTLE BLUESTEM P

Sporobolus cryptandrus (Torr.) A. Gray, SAND DROPSEED P

Sporobolus giganteus Nash, GIANT DROPSEED P $\downarrow$

Stipa hymenoides Roem. \& Shult. [Achnatherum hymenoides (Roem. \& Shult.) Barkworth; Oryzopsis hymenoides (Roem. \& Shult.) Ricker], INDIAN RICEGRASS P

Triplasis purpurea (Walter) Chapman, PURPLE SANDGRASS A

Vulpia octoflora (Walter) Rydb. [Festuca octoflora Walter], SIXWEEKS FESCUE A

\section{ANGIOSPERMS: DICOTS}

\section{AMARANTHACEAE}

Amaranthus arenicola I.M. Johnst., SANDHILL AMARANTH A Froelichia floridana (Nutt.) Moq., PLAINS SNAKE-COTtON A

\section{ANACARDIACEAE}

Rhus aromatica Aiton var. trilobata (Nutt.) A. Gray ex S. Watson $[R$. trilobata Nutt.], SKUNKBUSH SUMAC $P$

\section{ASCLEPIADACEAE}

Asclepias arenaria Torr., SAND MILKWEED $P$

Asclepias latifolia (Torr.) Raf., BROADLEAF MILKWEED P

\section{ASTERACEAE}

Ambrosia acanthicarpa Hook., ANNUAL BURSAGE A

Ambrosia psilostachya DC., WESTERN RAGWEED $P$

Aphanostephus ramosissimus DC., PLAINS LAZY DAISY A $\downarrow$

Artemisia filifolia Torr. [Oligosporus filifolius (Torr.) Poljakov], SAND SAGEBRUSH P
Cirsium canescens Nutt. [C. plattense (Rydb.) Cockerell], PLATTE THISTLE $\mathrm{B} / \mathrm{P} \uparrow$

Dieteria canescens (Pursh) Nutt. [Machaeranthera canescens (Pursh) A. Gray; M. linearis Greene; M. ramosa A. Nelson], HOARY TANSYASTER A/B $\uparrow$

Erigeron bellidiastrum Nutt., SANDHILLS FLEABANE $A$

Gaillardia pulchella Foug., BLANKET FLOWER A $\downarrow$

Gutierrezia sarothrae (Pursh) Britton \& Rusby, BROOM SNAKEWEED P

Helianthus petiolaris Nutt., PLAINS SUNFLower A

Heterotheca villosa (Pursh) Shinners [Chrysopsis villosa Nutt. ex DC.], HAIRY GOLDENASTER $P$

Hymenopappus flavescens A. Gray, YeLLow PLAINSMAN B $\downarrow$

Lorandersonia baileyi (Wooton \& Standl.) Urbatsch, R.P. Roberts, \& Neubig [Chrysothamnus baileyi Wooton \& Standl.; C. pulchellus (A. Gray) Green subsp. bailey (Wooton \& Standl.) H.M. Hall \& Clements], Balley's RabBITBRush P $\downarrow$ 
Lygodesmia juncea (Pursh) D. Don ex Hook., RUSH SKELETONWEed P Palafoxia rosea (Bush) Cory, Rosy PALAFOX A $\downarrow$

Palafoxia sphacelata (Nutt. ex Torr.) Cory, Othake A

Psilostrophe villosa Rydb., PAPER FLOWER B/P $\downarrow$

Senecio riddellii Torr. \& A. Gray, RIDDELL'S RAGWORT P

Xanthisma spinulosum (Pursh) D.R. Morgan \& R.L. Hartm. [Haploppapus spinulosus (Pursh) DC.; Macheranthera pinnatifida (Hook.) Shinners], SPINY GOLDENWEED $P$

\section{BORAGINACEAE}

Cryptantha minima Rydb., LITTLE CRYPTANTHA A

Heliotropium convolvulaceum (Nutt.) A. Gray [Euploca convolvulaceum Nutt.], BINDWEED HELIOTROPE $A$

Lithospermum incisum Lehm., FRINGED PUCCOON $\mathrm{P}$

Oreocarya suffruticosa (Torr.) Greene [Cryptanthajamesii (Torr.) Payson; C. cinerea (Greene) Cronquist var.jamesii (Torr.) Cronquist], JAMES' CRYPTANTHA P

\section{BRASSICACEAE}

Dimorphocarpa candicans (Raf.) Rollins [Dithyrea wislizeni Engelm. var. palmeri Payson; Dimorphocarpa palmeri (Payson) Rollins], SPECTACLE-POD A/B $\downarrow$

Physaria ludoviciana (Nutt.) O’Kane \& Al-Shehbaz [Lesquerella ludoviciana (Nutt.) S. Watson; L. argentea (Pursh) MacMill.], FOOTHILL BLADDERPOD $P \uparrow$

\section{CACTACEAE}

Opuntia macrorhiza Engelm. [O. humifusa (Raf.) Raf., misapplied], Western pricklypear $\mathrm{P}$

\section{CAMPANULACEAE}

Triodanis holzingeri McVaugh, HoLZINGER'S VENUS'-LOOKING-GLASS A

\section{CAPPARACEAE}

Polanisia dodecandra (L.) DC. subsp. trachysperma (Torr. \& A. Gray) Iltis [P. trachysperma Torr. \& A. Gray], RED-WHISKER CLAMMYWEED A

Polanisia jamesii (Torr. \& A. Gray) Iltis [Cristatella jamesii Torr. \& A. Gray], James' CLammyweed A

\section{CHENOPODIACEAE}

Chenopodium cycloides A. Nelson, SANDHILL GOOSEFOOT A

Chenopodium pratericola Rydb., DESERT GOOSEFOOT A

Corispermum americanum (Nutt.) Nutt., American bUgSeEd A

Cycloloma atriplicifolium (Spreng.) J.M. Coult., WINGED PIGWEED A

\section{CONVOLVULACEAE}

Evolvulus nuttallianus Schult., SHAGGY DWARF MORNING-GLORY P Ipomoea leptophylla Torr., BUSH MORNING-GLORY P

\section{EUPHORBIACEAE}

Croton texensis Müll. Arg., TeXAS CROTON A

Euphorbia carunculata Waterf. [Chamaesyce carunculata (Waterf.) Shinners], SAND-DUNE SANDMAT A $\downarrow$

Euphorbia missurica Raf.var. petaloidea (Engelm.) Dorn [Chamaesyce missurica (Raf.) Shinners; Euphobia petaloidea Engelm], PRAIRIE SANDMAT A

Euphorbia serpillifolia Pers. [Chamaesyce serpillifolia (Pers.) Small], thyme-leaf spurge A

Euphorbia strictior Holz., PANHANDLE SPURGE P $\downarrow$

Stillingia sylvatica L., QUEEN'S DELIGHT P $\downarrow$

\section{FABACEAE}

Astragalus ceramicus Sheldon var. filifolius (A. Gray) F.J. Herm. [Phaca longifolia (Pursh) Nutt.], PAINTED MILKVETCH P

Dalea arenicola (Wemple) B.L. Turner [D. purpurea Vent.var. arenicola (Wemple) Barneby], SANDHILL PURPLE PRAIRIE CLOVER P

Dalea cylindriceps Barneby [Petalostemon compactus Swezey], SANDSAGE PRAIRIE CLOVER $P$

Dalea lanata Spreng., WOOLY DALEA P $\downarrow$
Dalea villosa (Nutt.) Spreng. [Petalostemon villosum Nutt.], SILKY PRAIRIE CLOVER P

Indigofera miniata Ortega, SCARLET PEA P $\downarrow$

Lupinus pusillus Pursh, RUSTY LUPINE A

Mimosa rupertiana B.L. Turner [Schrankia occidentalis (Wooton \& Standl.) Standl.; M. quadrivalvis L. var. occidentalis (Wooton \& Standl.) Barneby], EASTERN CATCLAW P $\downarrow$

Pomaria jamesii (Torr. \& A. Gray) Walp. [Hoffmannseggia jamesii Torr. \& A. Gray; Caesalpina jamesii (Torr. \& A. Gray) Fisher], JAMES' RUSHPEA P

Psoralidium lanceolatum (Pursh) Rydb. [Psoralea lanceolata Pursh; Ladeania lanceolata (Pursh) A.N. Egan \& Reveal], LEMON SCURFPEA P

\section{LAMIACEAE}

Monarda pectinata Nutt., PLAINS BEEBALM A

Monarda punctata L., DOTTED BEEBALM A/B

\section{LINACEAE}

Linum berlandieri Hook. [L. rigidum Pursh var. berlandieri (Hook.) Torr. \& A. Gray], BERLANDIER'S FLAX A

\section{LOACEAE}

Mentzelia nuda (Pursh) Torr. \& A. Gray [M. stricta (Osterh.) Stevens], SAND LILY B

\section{MONTIACEAE}

Phemeranthus calycinus (Engelm.) Kiger [Talinum calycinum Engelm.], Great Plains fameflower $P$

\section{NYCTAGINACEAE}

Abronia fragrans Nutt. ex Hook., SWEET SAND VERBENA P

Mirabilis glabra (S. Watson) Standl. [= M. carletonii (Standl.) Standl. (Kelso et al. 2007); = M. exaltata (Standl.) Standl. (Rolfsmeier et al. 1999)], SMOOTH FOUR-O'CLOCK $P$

\section{ONAGRACEAE}

Oenothera albicaulis Pursh, WHITE EVENING PRIMROSE A

Oenothera cinerea (Wooton \& Standl.) W.L. Wagner \& Hoch subsp. cinerea [Gaura villosa Torr. subsp. villosa], HAIRY GAURA P $\downarrow$

Oenothera engelmannii (Small) Munz, ENGELMANN'S EVENING PRIMROSE A $\downarrow$

Oenothera latifolia (Rydb.) Munz [O. pallida Lindl. subsp. latifolia (Rydb.) Munz; Anogra cinerea Rydb.], PALE EVENING PRIMROSE P

Oenothera rhombipetala Nutt. ex Torr. \& A. Gray, FOUR-POINT EVENING PRIMROSE B

Oenothera serrulata Nutt. [Calylophus serrulatus (Nutt.) P.H. Raven], PLAINS YELLOW PRIMROSE $P$

\section{PAPAVERACEAE}

Argemone polyanthemos (Fedde) G.B. Ownbey, PRICKLY POPPY B

Corydalis aurea Willd. subsp. occidentalis (Engelm. ex A. Gray) G.B. Ownbey, GOLDEN CORYDALIS A

\section{PHYLLANTHACEAE}

Phyllanthus warnockii G.L. Webster [Reverchonia arenaria A. Gray], SAND REVERCHONIA A $\downarrow$

\section{PLANTAGINACEAE}

Penstemon ambiguus Torr., GILIA PENSTEMON P

Penstemon angustifolius Nutt. ex Pursh, NARROW-LEAf PENSTEMON P $\uparrow$ Penstemon buckleyi Pennell, BuckLey's PENSTEMON P $\downarrow$

Plantago patagonica Jacq. (P. purshii Roem. \& Schult.], wooly PLANTAIN A

\section{POLEMONIACEAE}

Ipomopsis longiflora (Torr.) V.E. Grant [Gilia longiflora (Torr.) G. Don], LONG-FLOWERED IPOMOPSIS A/B

Phlox andicola E.E. Nelson [P. douglasii Hook., misapplied; P. hoodii Hook., misapplied), PLAINS PHLOX P $\uparrow$

\section{POLYGONACEAE}

Eriogonum annuum Nutt., ANNUAL WILD BUCKWHEAT A/B 
Eriogonum effusum Nutt. [E. microthecum Nutt., misapplied], SPREADING WILD BUCKWHEAT $P \uparrow$

Rumex venosus Pursh, WILD BEGONIA P

\section{RANUNCULACEAE}

Delphinium carolinianum Walter subsp. virescens (Nutt.) R.E. Brooks [D. virescens Nutt.], PLAINS LARKSPUR P

\section{ROSACEAE}

Prunus angustifolia Marshall, CHICKASAW PLUM P $\downarrow$

Prunus pumila L. var. besseyi (L.H. Bailey) Waugh [P. besseyi L.H. Bailey], SAND CHERRY P $\uparrow$

\section{RUBIACEAE}

Hedyotis humifusa (A. Gray) A. Gray, MATTED bLUEt A $\downarrow$

\section{SANTALACEAE}

Comandra umbellata Bastard toadflax $\mathrm{P}$

\section{SOLANACEAE}

Physalis hispida (Waterf.) Cronquist [P. pumila Nutt. subsp. hispida (Waterf.) Hinton], SANDHILLS GROUND-CHERRY $P$

\section{ACKNOWLEDGMENTS}

The generosity of the Loveland Garden Club (Garden Club of America) of Omaha, Nebraska is gratefully acknowledged for providing funding in support of range-wide field work for this project. Funding from the Nebraska Game and Parks Commission facilitated sandsage prairie research in Nebraska. Thanks to the Colorado Field Office of The Nature Conservancy for providing access to preserves having sandsage prairie. I thank Dee Ebbeka of the University of Nebraska-Lincoln School of Natural Resources for preparation of the map used as Figure 1. The personal observations and insights of Nathan Andrews, Chris Helzer, Bruce Hoagland, and Gerry Steinauer helped bring clarity. Thanks to Kelly Kindscher, Steven Rolfsmeier, and an anonymous person for helpful review comments.

\section{REFERENCES}

AlLRED, B.W. 1949. Distribution and control of several woody plants in Texas and Oklahoma. J. Range Managem. 2:17-29. AlLreD, B.W. 1956. Mixed prairie in Texas. In: J.E. Weaver \& F.W. Albertson. Grasslands of the Great Plains. Johnsen Publishing Company, Lincoln, Nebraska, U.S.A. Pp. 267-283.

BARBER, S.C. 2008. A floristic study of the vascular plants of the Gypsum Hills and Redbed Plains area of southwestern Oklahoma. Oklahoma Native PI. Rec. 8:4-36.

BaRnes, P.W., A.T. HARRISON, \& S.P. HeINISCH. 1984. Vegetation patterns in relation to topography and edaphic variation in Nebraska Sandhills prairie. Prairie Naturalist 16:145-158.

BASKIN, J.M. \& C.C.BASKIN. 1985. Life cycle ecology of annual plant species of cedar glades of southeastern United States. In: J. White, ed. The population structure of vegetation. Dr. W. Junk Publishers, Dordercht, Netherlands. Pp. 371-398.

BERG, W.A. 1994. Sand sagebrush-mixed prairie. In: T.N. Shiflet, ed. Rangeland cover types of the United States. Society for Range Management, Denver, Colorado, U.S.A. P. 99.

BLAIR, W.F. \& T.H. HuBBeLL. 1938. The biotic districts of Oklahoma. Amer. Midl. Naturalist 20:425-454.

BLeED, A. \& C. FlowerDAY, eds. 1990. An atlas of the Sand Hills, $2^{\text {nd }}$ ed. Univ. of Nebraska-Lincoln Conservation and Survey Division Resource Atlas No. 5a. Lincoln, Nebraska, U.S.A.

Brown, D.E. 1994. Chihuahuan desertscrub. In: D.E. Brown, ed. Biotic communities southwestern United States and northwestern Mexico. Univ. of Utah Press, Salt Lake City, Utah, U.S.A. Pp. 169-179.

BRUNER, W.E. 1931. The vegetation of Oklahoma. Ecol. Monogr. 1:99-188.

BUtHoD, A.K. \& B.W. HOAGLAND. 2015. Contributions to the flora of Cimarron County and the Black Mesa area. Oklahoma Native PI. Rec. 15:49-77.

CARLTON, M.A. 1892. Observations on the native plants of Oklahoma Territory and adjacent districts. Contr. U.S. Nat. Herb. 1:220-232.

CLARK, D.A. 1996. A floristic survey of the Mesa de Maya region, Las Animas, Colorado. Natural History Inventory of Colorado No. 17. Univ. of Colorado Museum, Boulder, Colorado, U.S.A.

Collins, S.L., J.A. BRADFord, \& P.L. SIms. 1987. Succession and fluctuation in Artemisia dominated grassland. Vegetatio 73:89-99.

Colorado Natural Heritage Program (CNHP). 2005. Western Great Plains Sandhill Shrubland. Colorado Natural Heritage Program, Colorado State University, Fort Collins, Colorado, U.S.A.

Cordova, C.E., J.C. Porter, K. LepPeR, R. Kalchgruber, \& G. SCOtt. 2005. Preliminary assessment of sand dune stability along a bioclimatic gradient, north-central and northwestern Oklahoma. Great Plains Res. 15:227-249.

CorneluUs, D.R. \& M.D. AtKINs. 1946. Grass establishment and development studies in Morton County, Kansas. Ecology 27:342-353. 
Costello, D.F. 1944. Important species of the major forage types in Colorado and Wyoming. Ecol. Monogr. 14:107-134.

DaLEY, R.H. 1972. The native sand sage vegetation of eastern Colorado. MS thesis, Colorado State Univ., Fort Collins, Colorado, U.S.A.

DavIs, J.H., III, \& C.D. Bonham. 1979. Interference of sand sagebrush canopy with needleandthread. J. Range Managem. 32:384-386.

DHILlıon, S.S. \& M.H. MILLs. 1999. The sand shinnery oak (Quercus havardii) communities of the Llano Estacado: history, structure, ecology, and restoration. In: R.C. Anderson, J.S. Fralish, \& J.M. Baskin, eds. Savannas, barrens, and rock outcrop communities of North America, Cambridge Univ. Press, New York, U.S.A. and Cambridge, U.K. Pp. 262-274.

Dick-PeddiE, W.A. 1993. New Mexico vegetation: Past, present, and future. Univ. of New Mexico Press, Albuquerque, New Mexico, U.S.A.

Doxon, E.D., C.A. DAVIS, S.D. FuHLendoRF, \& S.L. WinTER. 2011. Aboveground macroinvertebrate diversity and abundance in sand sagebrush prairie managed with the use of pyric herbivory. Rangeland Ecol. Managem. 64:394-403.

DUCK, L.G. \& J.B. FLeTCHER. 1944. A survey of the game and furbearing animals of Oklahoma. State Bulletin 3. Oklahoma Game and Fish Commission, Oklahoma City, Oklahoma, U.S.A.

Elliott, L.F., A. Treuer-Kuehn, C.F. Blodgett, C.D. True, D. German, \& D.D. Diamond. 2009-2014. Ecological systems of Texas: 391 Mapped Types. Phase 1-6, 10-meter resolution Geodatabase, Interpretive Guides, and Technical Type Descriptions. Texas Parks \& Wildlife Department and Texas Water Development Board, Austin, Texas, U.S.A. Documents and Data Available at: http://www.tpwd.state.tx.us/gis/data/downloads\#EMS-T.

Evans, H.E. 1997. The natural history of the Long Expedition to the Rocky Mountains, 1819-1820. Oxford Univ. Press, New York, U.S.A.

FARRAR, J. 1993a. Sandsage prairie: A history of the land. NEBRASKAland 71:22-29.

FARRAR, J. 1993b. Sandsage prairie: The Cinderella sandhills. NEBRASKAland 71:30-41.

Fenneman, N.M. 1931. Physiography of the western United States. McGraw-Hill, New York, New York, U.S.A.

FREMONT, J.C. 1845. Report of the exploring expedition to the Rocky Mountains in the year 1842 and to Oregon and north California in the years 1843-44. United States 28th Congress, 2nd session. Senate Doc. 174. Gales and Seaton, printers, Washington, D.C.

GILLEN, R.L. \& P.L. SIMS. 2004. Stocking rate, precipitation, and herbage production on sand sagebrush-grassland. J. Range Managem. 57:148-152.

GiLLEN, R.L. \& P.L. Sims. 2006. Stocking rate and weather impacts on sand sagebrush and grasses: A 20-year record. Rangeland Ecol. Managem. 59:145-152.

Goodman, G.J. \& C.A. LAwson. 1995. Retracing Major Stephen H. Long's 1820 expedition: The itinerary and botany. Univ. of Oklahoma Press, Norman, Oklahoma, U.S.A.

Griffith, G.E., S.A. Bryce, J.M. Omernik, J.A. Comstock, A.C. Rogers, B. Harrison, S.L. Hatch, \& D. Bezanson. 2004. Ecoregions of Texas, U.S. Environmental Protection Agency, Corvallis, Oregon, U.S.A. (map scale 1:2,500,000).

Griffith, G.E., J.M. Omernik, M.M. McGraw, G.Z. Jacobi, C.M. Canavan, T.S. Schrader, D. Mercer, R. Hill, \& B.C. Moran. 2006. Ecoregions of New Mexico. U.S. Geological Survey. Reston, Virginia, U.S.A. (map scale 1:1,400,000).

GUNTER, S.A., E.T. THACKER, R.L. GILLEN, T.L. SPRINGER, \& R.D. JONES. 2012. Effects of sand sagebrush control in southern mixedgrass prairie rangeland on cattle performance and economic return. The Professional Animal Scientist 28:204-212.

HALEY, J.E. 1954. The XIT Ranch of Texas and the early days of the Llano Estacado. Univ. of Oklahoma Press, Norman, Oklahoma, U.S.A.

HANDLEY, J. \& W. Fertig. 2002. State Species Abstract: Cuscuta plattensis. Wyoming Natural Diversity Database. Available on the internet at www.uwyo.edu/wyndd.

HaRMS, R.T. 2014. A news species of Evolvulus (Convolvulacaea) from the High Plains of the Texas/New Mexico border. Phytologia 2014-20:1-20.

HazLetT, D.L. 1998. Vascular plant species of the Pawnee National Grassland. Gen. Tech. Rep RMRS-GTR-17, U.S. Department of Agriculture, Forest Service, Rocky Mountain Research Station, Fort Collins, Colorado, U.S.A.

Hazlett, D.L. 2004. Vascular plant species of the Comanche National Grassland in southeastern Colorado. Gen. Tech. Rep. RMRS-GTR-130. U.S. Department of Agriculture, Forest Service, Rocky Mountain Research Station, Fort Collins, Colorado, U.S.A.

HAZLETT, D.L., M.H. SCHIEBOUt, \& P.L. Ford. 2009. Vascular plants and a brief history of the Kiowa and Rita Blanca National Grasslands. Gen. Tech. Rep. RMRS-GTR-233. U.S. Department of Agriculture, Forest Service, Rocky Mountain Research Station, Fort Collins, Colorado, U.S.A. 
Heerwagen, A. 1956. Mixed prairie in New Mexico. In: J.E. Weaver \& F.W. Albertson, eds. Grasslands of the Great Plains. Johnsen Publishing Company, Lincoln, Nebraska, U.S.A. Pp. 284-300.

HeIDEL, B. 2012. Status of Penstemon haydenii (Blowout Penstemon) in Wyoming, 2012. Prepared for the Bureau of Land Management - Rawlins and Rock Springs Field Offices and Wyoming State Office. Wyoming Natural Diversity Database, Univ. of Wyoming, Laramie, Wyoming, U.S.A.

HІтснсоск, A.S. 1896. Report on a collection on plants made by C.H. Thompson in southwestern Kansas in 1893. Contr. U.S. Natl. Herb. 3:537-557.

НІтснсоск, A.S. 1898. Ecological plant geography of Kansas. Trans. Acad. Sci. St. Louis 8:55-69.

HoAgLAND, B.W. 2000. Vegetation of Oklahoma: a classification for landscape mapping and conservation planning. S. W. Naturalist 45:385-420.

HoagLand, B.W. 2008. Vegetation of Oklahoma. Map, 1: 2,000,000. In: K.S. Johnson \& K.V. Luza, eds. Earth sciences and mineral resources of Oklahoma. Oklahoma Geological Survey Education Publ. 9. P. 17.

Hulett, G.K., C.D. SloAn, \& G.W. Tomanek. 1968. The vegetation of remnant grasslands in the Loessial Region of northwestern Kansas and southwestern Nebraska. S. W. Naturalist 13:377-391.

Hulett, G.K., J.R. TomelleRI, \& C.O. Hampton. 1988. Vegetation and flora of a sandsage prairie site in Finney County, southwestern Kansas. Trans. Kansas Acad. Sci. 91:83-95.

JACKSON, A.S. 1965. Wildfires in the Great Plains grasslands. Proc. Tall Timbers Fire Ecology Conf. 4:241-259.

JAMES, E. (compiler). 1823. Account of an expedition from Pittsburgh to the Rocky Mountains, performed in the years 1819 and '20...under the command of Major Stephen H. Long. H.C. Carey and I. Lea, Philadelphia, Pennsylvania, U.S.A.

JohnsGaRd, P.A. 1995. This fragile land: A natural history of the Nebraska Sandhills. Univ. of Nebraska Press, Lincoln, Nebraska, U.S.A.

KAUL, R.B. \& S.B. RolfsmeleR. 1993. Native vegetation of Nebraska. Map, 1: 1,000,000, 16 colors. Conservation and Survey Division, Univ. of Nebraska-Lincoln, Lincoln, Nebraska, U.S.A.

Kaul, R.B., D. Sutherland, \& S. Rolfsmeier. 2011. The flora of Nebraska, $2^{\text {nd }}$ ed. School of Natural Resources, Univ. of Nebraska-Lincoln, Lincoln, Nebraska, U.S.A.

KeELER, K.H. 1987. Survivorship and fecundity of the polycarpic perennial Mentzelia nuda (Loasaceae) in Nebraska Sandhills prairie. Amer. J. Bot. 74:785-791.

Kelso, T., N. Bower, P. Halteman, K. Tenney, \& S. Weaver. 2007. Dune communities of SE Colorado: Patterns of rarity, disjunction and succession. In: P. Barlow-Irick, J. Anderson, \& C. McDonald, eds. Southwestern rare and engendered plants: Proc. Fourth Conference; 22-26 Mar 2004, Las Cruces, New Mexico. RMRS-P-48CD, U.S. Department of Agriculture, Forest Service, Fort Collins, Colorado, U.S.A. Pp. 39-48.

KNIGHT, D.H. 1994. Mountains and plains: The ecology of Wyoming landscapes. Yale Univ. Press, New Haven, Connecticut, U.S.A.

KoERTH, B.H., L.J. KRYSL, B.F. SoweLL, \& F.C. BRYANt. 1984. Estimating seasonal diet quality of pronghorn antelope from fecal analysis. J. Range Managem. 37:560-564.

KuCHLER, A.W. 1964. Potential natural vegetation of the conterminous United States (1:3,168,000 scale map), American Geographical Society, Washington, D.C. Special Publ. No. 36.

KUCHLER, A.W. 1974. A new vegetation map of Kansas. Ecology 55:586-604.

Kuhn, B., B.E. Nelson, \& R.L. Hartman. 2011. A floristic inventory of the Cimarron National Grassland (Kansas) and the Comanche National Grassland (Colorado). J. Bot. Res. Inst. Texas 5:753-772.

LADYMAN, J.A.R. 2006. Chenopodium cycloides A. Nelson (sandhill goosefoot): A technical conservation assessment [Online]. USDA Forest Service, Rocky Mountain Region. Available: http://www.fs.fed.us/r2/projects/scp/assessments/chenopodiumcycloides.pdf.

LAUnCHBAUGH, J.L. \& C.E. OwensBy. 1978. Kansas rangelands: Their management based on a half century of research. Kansas Agricultural Experiment Station Bulletin 622.

Lauver, C.L., K. Kindscher, D. Faber-Langendoen, \& R. Schneider. 1999. A classification of the natural vegetation of Kansas. S. W. Naturalist 44:421-443.

LOCKLEAR, J.H. 2013. Taxonomic identity and historical accounts of Dalea cylindriceps Barneby (Fabaceae), a species of conservation concern in the Great Plains (U.S.A.). J. Bot.Res. Inst. Texas 7:879-890.

LoCKLEAR, J.H. 2017a. Endemic plants of the Central Grassland of North America: Distribution, ecology, and conservation status. J. Bot. Res. Inst. Texas 11:193-234. 
LoCKLEAR, J.H. 2017b. Sandsage Prairie Biologically Unique Landscape rare plant survey. Report prepared for the Nebraska Natural Heritage Program, Nebraska Game and Parks Commission by Lauritzen Gardens, Omaha, Nebraska, U.S.A.

MacMahon, J.A. 2000. Warm deserts. In: M.G. Barbour \& WD. Billings, eds. North American terrestrial vegetation, ed. 2. Cambridge Univ. Press, New York, U.S.A. and Cambridge, U.K. Pp. 285-322.

MADOLE, R.F. 1995. Spatial and temporal patterns in late Quaternary eolian deposition, eastern Colorado, U.S.A. Quatern. Sci. Rev. 14:155-177.

Madole, R.F., D.P. VanSISTINe, \& J.A. Michael. 2005. Distribution of Late Quaternary wind-deposited sand in eastern Colorado. U.S. Geological Survey Scientific Investigations Map 2877, scale 1:700,000, 49 p. pamphlet.

MaxweLL, M.H. \& L.N. Brown. 1968. Ecological distribution of rodents on the High Plains of eastern Wyoming. S. W. Naturalist 13:143-158.

McGinnies, J.J., H.L. SChantz, \& W.C. McGinnies. 1991. Changes in vegetation and land use in eastern Colorado: A photographic study, 1904 to 1986. U.S. Department of Agriculture, Agricultural Research Service, ARS-85.

Milchunas, D.G., W.K. Lauenroth, I.C. Burke, \& J.K. Detuing. 2008. Effects of grazing on vegetation. In: W.K. Lauenroth \& I.C. Burke, eds. Ecology of the shortgrass steppe: A long-term perspective. Oxford Univ. Press, New York, U.S.A. Pp. 389-446.

Miller, R.F., S.T. KnICK, D.A. PYke, C.W. Meinke, S.E. HANSER, M.J. Wisdon, \& A.L. HiLD. 2011. Characteristics of sagebrush habitats and limitations to long-term conservation. In: S.T. Knick \& J.W. Connelly, eds. Greater sage-grouse: ecology and conservation of a landscape species and its habitats. Studies in Avain Biology (vol. 38), Univ. of California Press, Berkeley, California, U.S.A. Pp. 145-185.

MuHS, D.R. \& V.T. HolLIDAY. 1995. Evidence of active dune sand on the Great Plains in the $19^{\text {th }}$ century from accounts of early explorers. Quatern. Res. 43:198-208.

Muns, D.R. \& V.T. Holliday. 2001. Origin of late Quaternary dune fields on the Southern High Plains of Texas and New Mexico. Bull. Geol. Soc. Amer. 113:75-87.

Muhs, D.R., T.W. Stafford, JR., S.D. Cowherd, S.A. Mahan, R. Kint, P.B. MaAt, C.A. Bush, \& J. Nehring. 1996. Origin of the late Quaternary dune fields of northeastern Colorado. Geomorphology 17:129-149.

NatureServe. 2019. NatureServe Explorer: An online encyclopedia of life [web application]. Version 7.1. NatureServe, Arlington, Virginia, U.S.A. Available http://www.natureserve.org/explorer.

Neid, S., J.E. Stevens, K. Forest, \& M. Fink. 2007. Sand Creek Massacre National Historic Site: Vegetation classification and mapping. Natural Resource Technical Report NPS/SOPN/NRTR-2007/050. National Park Service, Fort Collins, Colorado, U.S.A.

Nesom, G.L. \& R.J. O'KenNon. 2008. Major plant communities of Lake Meredith National Recreational Area and Alibates Flint Quarries National Monument. Phytologia 90:391-405.

Peterson, R.S. \& C.S. Boyd. 1998. Ecology and management of sand shinnery communities: A literature review. Gen. Tech. Rep. RMRS-GTR-16. U.S. Department of Agriculture, Forest Service, Rocky Mountain Research Station, Fort Collins, Colorado, U.S.A.

Pielke, R.A., JR., \& N.J. Doesken. 2008. Climate of the shortgrass steppe. In: W.K. Lauenroth \& I.C. Burke, eds. Ecology of the shortgrass steppe: A long-term perspective. Oxford Univ. Press, New York, U.S.A. Pp. 14-29.

PLATT, W.J. 1975. The colonization and formation of equilibrium plant species associations on badger disturbances in a tall-grass prairie. Ecol. Mongr. 45:285-305.

PooL, R.J. 1914. A study of the vegetation of the Sandhills of Nebraska. Minnesota Bot. Stud. 4:189-312.

Pound, R. \& F.E. Clements. 1900. The phytogeography of Nebraska: General survey, $2^{\text {nd }}$ ed. Botanical Seminar, Univ. of Nebraska, Lincoln, Nebraska, U.S.A.

Powell, A.M. \& R.D. Worthington. 2018. Flowering plants of Trans-Pecos Texas and adjacent areas. Bot. Misc. 49, Botanical Research Institute of Texas Press, Fort Worth, Texas, U.S.A.

RAmALEY, F. 1939. Sand-hill vegetation of northeastern Colorado. Ecol. Monogr. 9:1-51.

RaWling, J.E., 3RD, G.G. FredLund, \& S. Mahan. 2003. Aeolian cliff-top deposits and buried soils in the White River Badlands, South Dakota, USA. Holocene 13:121-129.

RichaRDS, E.L. 1968. Vascular plants of Morton County, Kansas. Trans. Kansas Acad. Sci. 71:154-165.

Rogers, C.M. 1953. The vegetation of the Mesa de Maya region of Colorado, New Mexico, and Oklahoma. Lloydia 16:257-290.

Rolfsmeier, S.B. \& G. Steinauer. 2010. Terrestrial ecological systems and natural communities of Nebraska; Nebraska Natural Heritage Program, Nebraska Game and Parks Commission, Lincoln, Nebraska, U.S.A. 
Rolfsmeier, SB., R.F. Steinauer, \& D.M. Sutherland. New floristic records for Nebraska-5. Trans. Nebraska Acad. Sci. 25:15-22. RondeAu, R.J. 2003. Vegetation monitoring at Pueblo Chemical Depot: 1998-2002. Colorado Natural Heritage Program, Colorado State Univ., Fort Collins, Colorado, U.S.A.

Rondeau, R.J. 2013. Vegetation monitoring at Pueblo Chemical Depot: 1999-2010. Colorado Natural Heritage Program, Colorado State Univ., Fort Collins, Colorado. U.S.A.

RondeAu, R.J., K.L. DECKER, \& G.A. DoyLE. 2018. Potential consequences of repeated severe drought for shortgrass steppe species. Rangeland Ecol. Managem. 71:91-97.

Rondeau, R., K. DeCker, J. Handwerk, J. Siemers, L. Grunau, \& C. Pague. 2011. The state of Colorado's biodiversity. Prepared for The Nature Conservancy by the Colorado Natural Heritage Program, Colorado State Univ., Fort Collins, Colorado, U.S.A.

RoweLL, C.M., JR. 1967. Vascular plants of the Texas Panhandle and South Plains. PhD diss., Oklahoma State Univ., Stillwater, Oklahoma, U.S.A.

RUSH, M.S., S.M. ROYAL, \& E.D. FLEHARTY. 1982. New county records and habitat preferences of amphibians and reptiles from the sandsage prairie in Finney County, Kansas. Trans. Kansas Acad. Sci. 85:165-173.

SCHAAL, B.A. \& W.J. LEVERICH. 1982. Survivorship patterns in an annual plant community. Oecologia 54:149-151.

SCHMEISSER, R.L., D.B. Loope, \& J.A. MASON. 2010. Modern and Late Holocene wind regimes over the Great Plains (central U.S.A.). Quatern. Sci. Rev. 29:554-566.

SEXson, M.L. 1983. Destruction of sandsage prairie in southwest Kansas. In: C.L. Kucera, ed. Proc. Seventh North American Prairie Conference, 4-6 Aug 1980, Temple Hall, Southwest Missouri State Univ., Springfield, Missouri, U.S.A. Pp. 113-115.

SHANTZ, H.L. 1911. Natural vegetation as an indicator of the capabilities of land for crop production in the Great Plains area. U.S.D.A Bur. PI. Industr. Bull. 201.

ShAW, R.B., S.L. ANDERSON, K.A. Schultz, \& V.E. DieRSIng. 1989. Plant communities, ecological checklist, and species list for the U.S. Army Piñon Canyon Maneuver Site, Colorado. Range Science Series 37. Department of Range Science, Colorado State Univ., Fort Collins, Colorado, U.S.A.

SHERWOOD, R.T.B. \& P.G. RisSER. 1980 Annotated checklist of the vascular plants of Little Sahara State Park, Oklahoma. S. W. Naturalist 25:323-338.

SimonetT, D.S. 1960. Development and grading of dunes in western Kansas. Ann. Assoc. of Amer. Geog. 50:216-241.

Sims, P.L., B.E. DaHL, \& A.H. DenHam. 1976. Vegetation and livestock grazing response at three grazing intensities on sandhill rangeland in eastern Colorado. Colorado State Univ. Exp. Stat. Techn. Bull. No. 130.

Sims, S.L., J.A. BRAdFoRD, \& P.L. Sims. 1987. Succession and fluctuation in Artemisia dominated grassland. Vegetatio 73:89-99.

SoweLL, B.F., B.H. Koerth, \& F.C. Bryant. 1985. Seasonal nutrient estimates of mule deer diets in the Texas Panhandle. J. Range Managem. 38:163-167.

SPARKS, D.R. 1968. Diet of black-tailed jackrabbits on sandhill rangeland in Colorado. J. Range Managem. 21:203-208.

Steinauer, G. \& S. Rolfsmeier. 2010. Terrestrial natural communities of Nebraska. Nebraska Game and Parks Commission. Lincoln, Nebraska, U.S.A.

StUBBendieCK, J., T.R. FlessneR, \& R.R. WeEDon. 1989. Blowouts in the Nebraska Sandhills: The habitat of Penstemon haydenii. In: T.B. Bragg \& J. Stubbendieck, eds. Proc. Eleventh North American Prairie Conference, Univ. of Nebraska-Lincoln, U.S.A., 7-11 Aug 1988. Pp. 223-225.

SUtHeRLAND, D.M. \& S.B. RolFSMEIER. 1989. An annotated list of the vascular plants of Keith County, Nebraska. Trans. Nebraska Acad. Sci. 17:83-101.

THACKER, E., D. ELMORE, B. REAVIS, \& T. BIDWELL. 2017. Management of sand sagebrush rangelands. Oklahoma Cooperative Extension Service NREM-2892, Oklahoma State Univ., Stillwater, Oklahoma, U.S.A.

Thilenius, J.F., G.R. Brown, \& A.L. Medina. 1995. Vegetation on semi-arid rangelands, Cheyenne River Basin, Wyoming. Gen. Tech. Rep. RM-GTR-263. U.S. Department of Agriculture, Forest Service, Rocky Mountain Research Station, Fort Collins, Colorado, U.S.A.

TOLSTEAD, W.L. 1942. Vegetation of the northern part of Cherry County, Nebraska. Ecol. Monogr. 12:255-292.

VAN NimwEGen, R.E., J. KRETZER, \& J.F. CULLY, JR. 2008. Ecosystem engineering by a colonial mammal: How prairie dogs structure rodent communities. Ecology 89:3298-3305.

VermeIER, L.T., R.B. MitcheLL, \& S.D. FuHLendorf. 2001. Sand sagebrush response to fall and spring prescribed burns. In: E. McArthur \& D.J. Fairbanks, comps. Shrubland ecosystem genetics and biodiversity: Proc.; 13-15 Jun 2000, Provo, Utah, U.S.A. RMRS-P-21. U.S. Department of Agriculture, Forest Service, Ogden, Utah, U.S.A. Pp. 233-235. 
Von Loh, J., D. Cogan, D. Faber-Langendoen, D. Crawford, \& M. Pucherelli. 1999. USGS-NPS Vegetation Mapping Program, Badlands National Park, South Dakota (Final Report). USDI Bureau of Reclamation Technical Memorandum No. 826099-02. Denver, Colorado, U.S.A.

WATERFALL, U.T. 1948. A new species of Euphorbia from Oklahoma. Rhodora 50:63-64.

WEAVER, J.E. 1919. The ecological relations of roots. Publ. Carnegie Inst. Wash. 286.

WEAVER, J.E. 1958. Summary and interpretation of underground development in natural grassland communities. Ecol. Monogr. 28:55-78.

Weaver, J.E. \& F.W. Albertson. 1956. Grasslands of the Great Plains: Their nature and use. Johnsen Publishing Company, Lincoln, Nebraska, U.S.A.

WEST, N.E. \& J.A. Young. 2000. Intermountain valleys and lower mountain slopes. In: M.G. Barbour \& W.D. Billings, eds. North American terrestrial vegetation, ed. 2. Cambridge Univ. Press, New York, U.S.A. and Cambridge, U.K. Pp. 255-284.

WHITE, R.S. \& P.O. CURRIE. 1983. The effects of prescribed burning on silver sagebrush. J. Range Managem. 36:611-613.

Winter, S.L., S.D. Fuhlendorf, C.L. GoAd, C.A. DAvis, \& K.R. HICKMAN. 2011 a. Topoedaphic variability and patch burning in sand sagebrush shrubland. Rangeland Ecol. Managem. 64:633-640.

Winter, S.L., S.D. Fuhlendorf, C.L. Goad, C.A. Davis, K.R. Hickman, \& D.M. LesLie, JR. 2011 b. Fire tolerance of a resprouting Artemisia (Asteraceae) shrub. PI. Ecol. 212:2085-2094.

Winter, S.L., S.D. Fuhlendorf, C.L. GoAd, C.A. DAVIS, K.R. HICKMAN, \& D.M. LESLIE, JR. 2012. Restoration of the fire-grazing interaction in Artemisia filifolia shrubland. J. Appl. Ecol. 49:242-250.

WISHART, D.J. 2013. Last days of the Rainbelt. Univ. of Nebraska Press, Lincoln, Nebraska, U.S.A.

Wislizenus, A. 1848. Memoir of a tour to northern Mexico, connected with Col. Doniphan's Expedition in 1846 and 1847. United States 30th Congress, 1st session. Misc. no. 26. Tippin \& Streeper, printers, Washington, D.C.

WORSTER, D. 1979. Dust Bowl: The southern plains in the 1930s. Oxford Univ. Press, New York, U.S.A. 